\title{
Numerical seismic vulnerability analysis of mid-height steel buildings in Bogotá, Colombia
}

\author{
F. López-Almansa $a^{\mathrm{a}}$ (corresponding author), M.A. Montaña ${ }^{\mathrm{b}}$ \\ ${ }^{a}$ Department of Architecture Structures, Technical University of Catalonia, Avda. Diagonal 649, 08028 \\ Barcelona, Spain. E-mail: francesc.lopez-almansa@upc.edu. Phone:+34-93-4016316 \\ ${ }^{\mathrm{b}}$ Department of Geotechnical Engineering and Geo-Sciences, Technical University of Catalonia, Campus Nord \\ UPC, 08034 Barcelona, Spain. miguelmontaa@yahoo.es
}

\section{SUMMARY:}

A number of mid-height steel buildings have been erected recently in Bogotá. Their seismic risk might be high, given the present microzonation of Bogotá and the lack of comprehensive previous studies; noticeably, the response reduction factors were commonly obtained only from general recommendations. The objective of this work is to investigate the seismic performance of these buildings. This study is carried out on eighteen representative prototype buildings. All these edifices have plan symmetry and are uniform along their height. The eighteen considered prototype buildings are generated by combining the values of three parameters: span-length ( 6 and $8 \mathrm{~m})$, number of floors $(5,10$ and 15) and earthquake-resistant systems (moment-resistant frames, concentrically-braced frames and eccentrically-braced frames -using chevron braces-). The structures of each of these eighteen prototype buildings have been designed according to the former and to the current Colombian seismic design codes; in the former code two seismic zones are considered and in the current code such zones are coarsely subdivided in three and in five zones, respectively. The structural properties of the buildings designed with the former and the current Colombian codes are compared to investigate the practical repercussions of the new regulation. The vulnerability of these buildings has been evaluated by 2-D “push-over" analyses. The main objective of these analyses is to determine the response reduction factor; the obtained values are compared with the recommendations of the current Colombian seismic design code. As well, the seismic performance of the three considered earthquake-resistant systems are compared. 
Keywords: seismic vulnerability, steel buildings, push-over analysis, retrofit, Colombia.

\section{INTRODUCTION}

Steel construction provides two major earthquake-resistant qualities: lightweight and ductility; conversely, steel structures exhibit a rather low inherent damping. Globally speaking, the earthquake-resistant design of steel buildings tries to take profit of both advantages while attempting to compensate this drawback. Three major earthquake-resistant solutions have been proposed: MRF (moment-resistant frames), CBF (concentrically-braced frames) and EBF (eccentrically-braced frames). Other less frequent solutions have been also considered; among them: dual systems, special truss moment frames, outrigger walls, base isolation and energy dissipators. The concentrically braced frames are laterally stiffened by bracing members; "concentrically" means that, in the connections between beams, columns and braces, all the axes of the members are intersected in a single point. Conversely, in the eccentrically braced frames such axes do not intersect in a single point. The purpose of this strategy is to force the formation of hinges in the sections of the members where the braces fall on; the segments comprised between such hinges constitute the dissipative parts of the structure and are commonly termed as "links". In both the concentric and eccentric bracing systems, two major types of bracing members have been proposed: diagonal (X-shaped) and chevron (V-shaped or inverted V-shaped); globally speaking, diagonal braces are slightly more efficient while chevron braces are commonly preferred because of the higher availability of space for openings.

A number of mid-height steel buildings have been erected in the last years in Colombia, 
principally in Bogotá; they are mostly intended for dwelling, administrative and commercial use. These constructions have been designed according to the former Colombian seismic code [1], which was basically inspired by the American regulations, mainly those by FEMA, ATC, ASCE and AISC. The seismic risk of these buildings might be high, given that a new microzonation of Bogotá has been recently released [2] and that no comprehensive theoretical studies about their vulnerability have been carried out; in particular, the values of the response reduction factor $(R)$ are commonly obtained only from general recommendations that do not account for the individual characteristics of each building. The objective of this work is to investigate the seismic performance of these buildings in order to provide more accurate estimates of the response reduction factor and to be able to formulate design criteria; these recommendations might be incorporated to the Colombian seismic design code. As well, retrofit strategies will be proposed in further studies.

This study is carried out on eighteen prototype buildings [3] that have been selected to represent the vast majority of the existing ones. All these types of prototype buildings have plan symmetry and are uniform along their height; in half of them the span-length is $6 \mathrm{~m}$ in both directions (this corresponds mainly to housing use), while in the others it is $8 \mathrm{~m}$ (mainly for commercial and administrative use). Three earthquake-resistant systems have been considered: moment-resistant frames (MRF), concentrically-braced frames (CBF) and eccentrically-braced frames $(\mathrm{EBF})$; in these last two cases, chevron braces are contemplated. The numbers of floors are 5, 10 and 15 . The structure of each of the eighteen prototype buildings is designed for a given seismic zone in Bogotá. According to the former microzonation [4] two zones are considered and the structure is designed for the previous Colombian regulation [1]; according to the newer microzonation [2] eight zones are considered and the structure is designed for the current Colombian regulation [5]. 
The seismic vulnerability of these buildings has been evaluated, in the framework of the Performance-Based Design [6], by static nonlinear analyses (push-over). The structural behavior of the buildings is described by finite element models with frame elements; the cooperation of the top concrete layer of the slabs is neglected. In the moment-resistant frames and in the eccentrically-braced frames the nonlinearities are concentrated in the plastic hinges located near the connections. In the concentrically-braced frames, prior to the buckling of the compressed braces the nonlinearities are concentrated there; afterwards, there also plastic hinges near the connections. In the push-over analyses, two vertical distributions of the pushing horizontal forces are considered: uniform pattern and modal pattern (e.g. shaped as the first mode of vibration) [7]. The target drifts (performance points) are determined, for each performance objective (IO, LS and CP) according to the recommendations of the ATC$40[8]$.

The results of the push-over analyses provide estimates of the response reduction factor; it is concluded that, in some cases, the values recommended by the design code are unconservative. As well, some of the buildings exhibit inadequate behavior for several performance objectives.

\section{SEISMIC MICROZONATIONS OF BOGOTÁ}

This section describes the former and the current seismic microzonations that have been proposed for Bogotá.

Figure 1 shows the former microzonation of Bogotá [4]. In Figure 1 "Cerros" corresponds to rock and stiff soil, "Piedemonte" refers to good quality colluvial soil and alluvial fans, and 
"Lacustre A" and "Lacustre B" correspond to soft clay deposits whose depth is higher and smaller than $50 \mathrm{~m}$, respectively. "Terrazas y Conos" are terraces and alluvial fans, "Rondas de río y humedales" are river banks and swamps and "Rellenos de Basuras" and "Rellenos de Excavación" are rubbish and dig dumps, respectively. In this study only zones "Piedemonte" and "Lacustre A" have been considered. The other seismic zones indicated in Figure 1 are not considered since they contain only small numbers of steel buildings. Figure 2 displays the design spectra of these two zones.
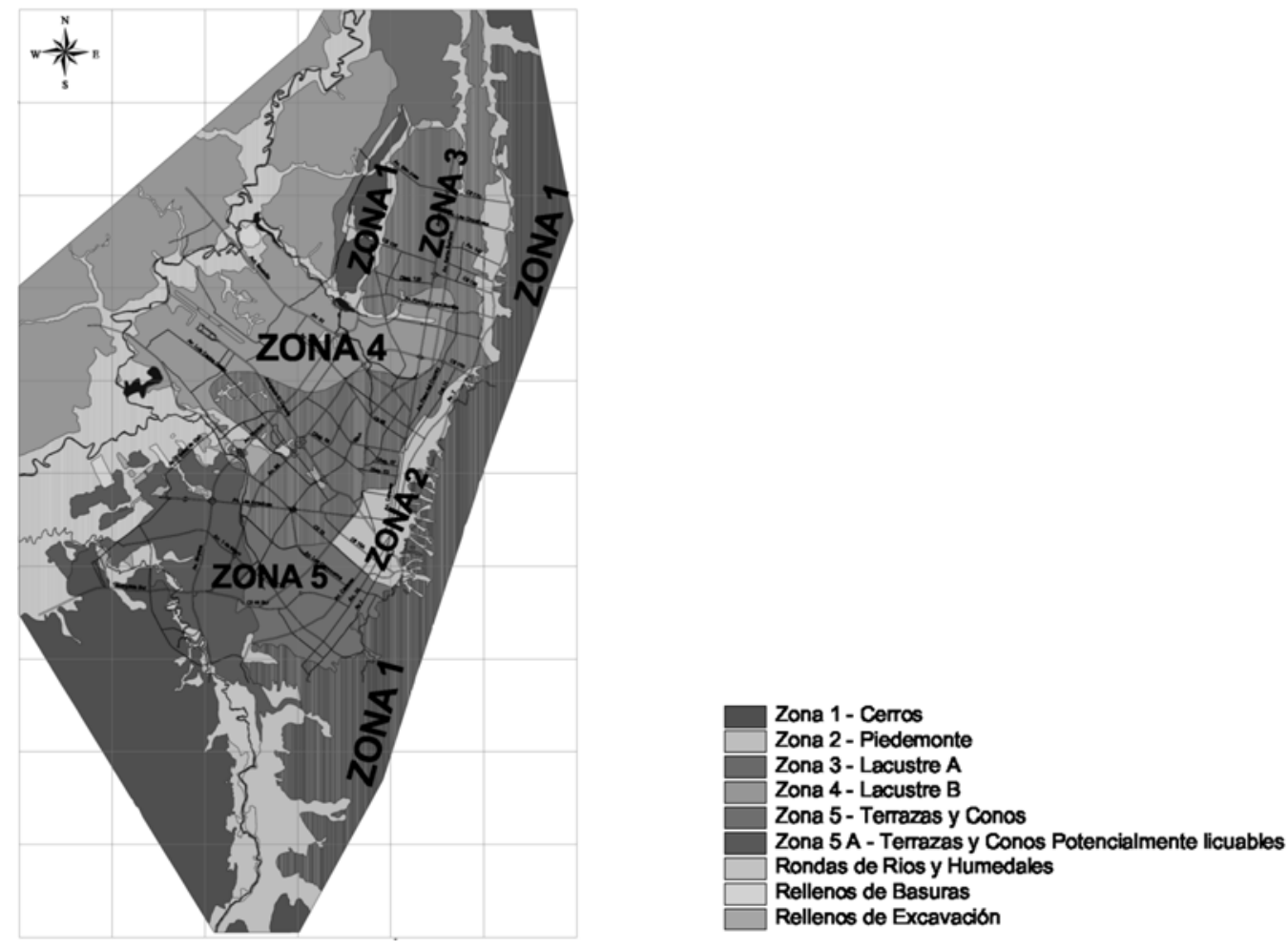

Figure 1. Former seismic microzonation of Bogotá [4] 


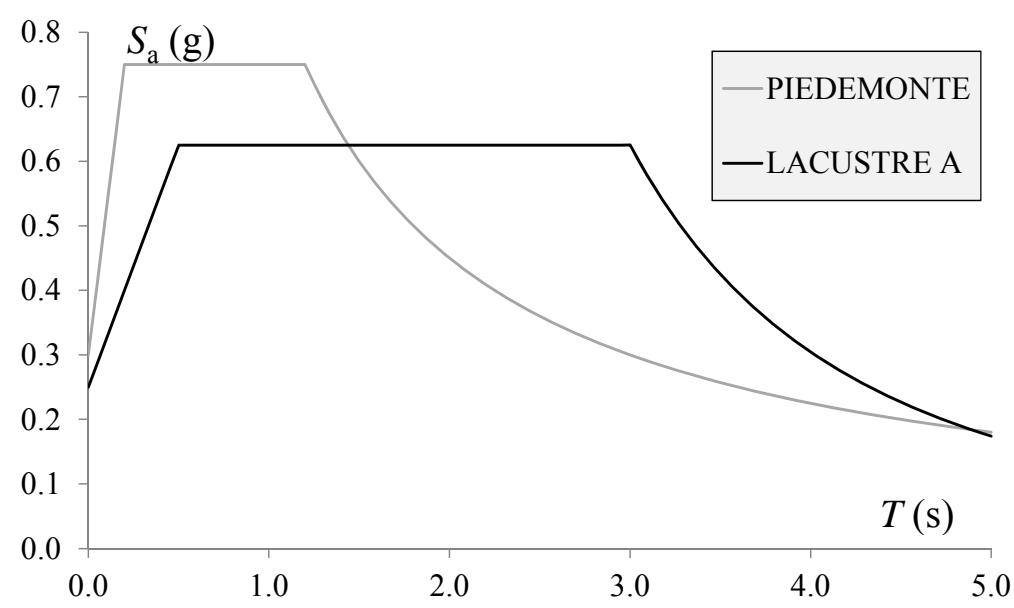

Figure 2. Design spectra according to the former seismic microzonation of Bogotá [4]

Figure 3 displays the abovementioned current seismic microzonation of Bogotá [2]. In Figure 3 "Cerros" corresponds to rock and stiff soil with top soft layers not exceeding $6 \mathrm{~m}\left(v_{\mathrm{s}, 30}>\right.$ $750 \mathrm{~m} / \mathrm{s}$, where $v_{\mathrm{s}, 30}$ accounts for the shear wave velocity in the top $30 \mathrm{~m}$ ), "Piedemonte" refers to soft alluvial and colluvial soil $\left(200 \mathrm{~m} / \mathrm{s}<v_{\mathrm{s}, 30}<750 \mathrm{~m} / \mathrm{s}\right)$ and "Lacustre" corresponds to very soft clay deposits $\left(v_{\mathrm{s}, 30}<175 \mathrm{~m} / \mathrm{s}\right)$. As well "Aluvial" refers to midquality alluvial deposits $\left(175 \mathrm{~m} / \mathrm{s}<v_{\mathrm{s}, 30}<300 \mathrm{~m} / \mathrm{s}\right)$ and "Lacustre-Aluvial" shows intermediate characteristics in between "Aluvial" and "Lacustre". Finally "Depósito ladera" are unstable high slope soils, with relevant risk of land-sliding; the construction is restricted. In the categories "Lacustre", "Aluvial" and "Lacustre-Aluvial", the numbers indicate the depth (in m) of the soft deposit layers. In the category "Piedemonte", subcategories A, B and C do not differ deeply. In this study only zones "Piedemonte A, B and C" and "Lacustre 50, 100, 200, 300 and 500" have been considered. The other seismic zones indicated in Figure 3 are not considered since they contain only small numbers of steel buildings. 

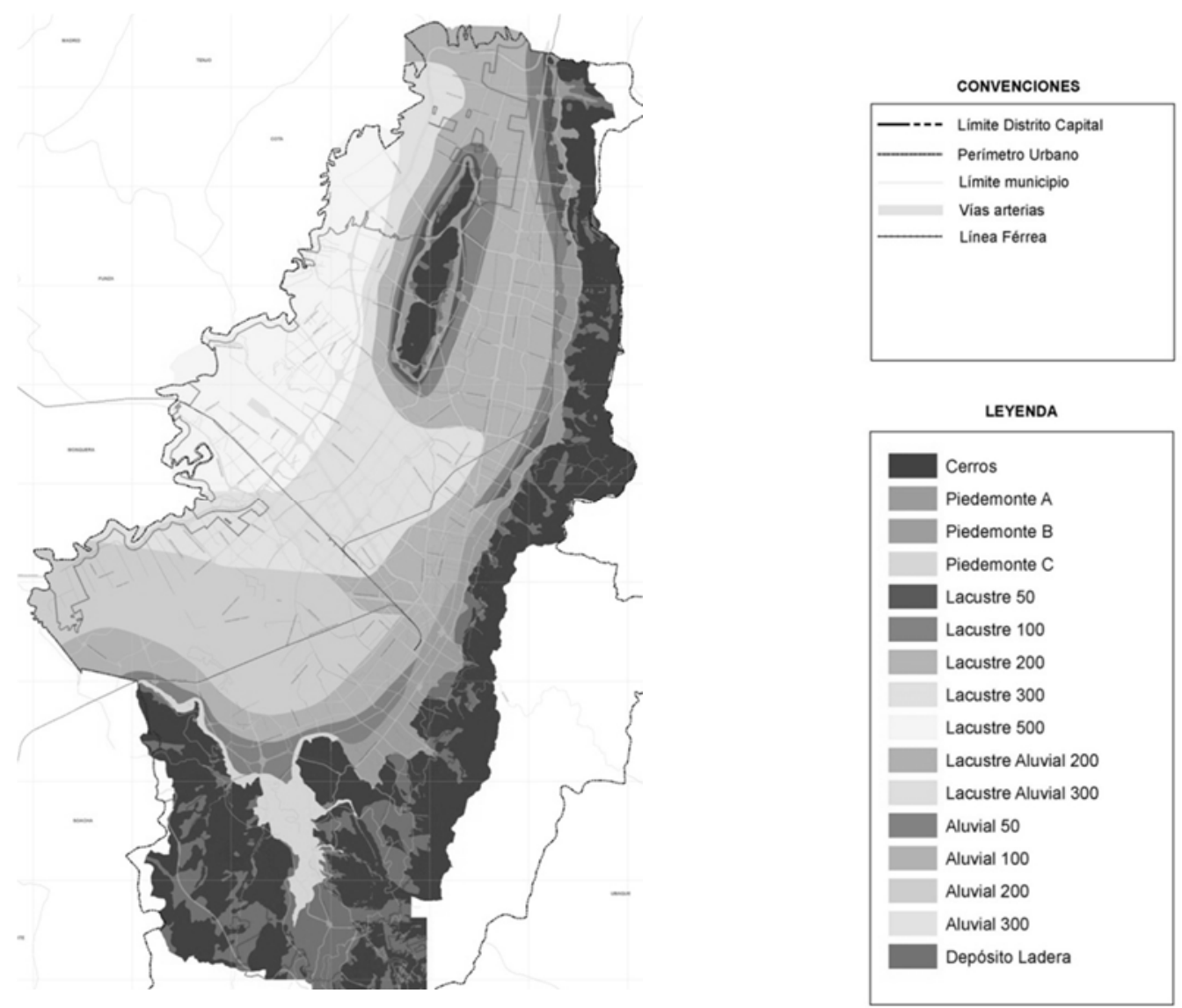

Figure 3. Current seismic microzonation of Bogotá [2]

Comparison between the two microzonations depicted in Figure 1 and in Figure 3 shows that the main difference is that the newer microzonation consists basically in a refinement of the previous one. In the former microzonation (Figure 1) zones "Piedemonte" and "Lacustre A" have been considered; in the current microzonation (Figure 3) such zones are split in "Piedemonte A, B and C" and in "Lacustre 50, 100, 200, 300 and 500", respectively. Figure 4 displays the design spectra of these eight zones. 


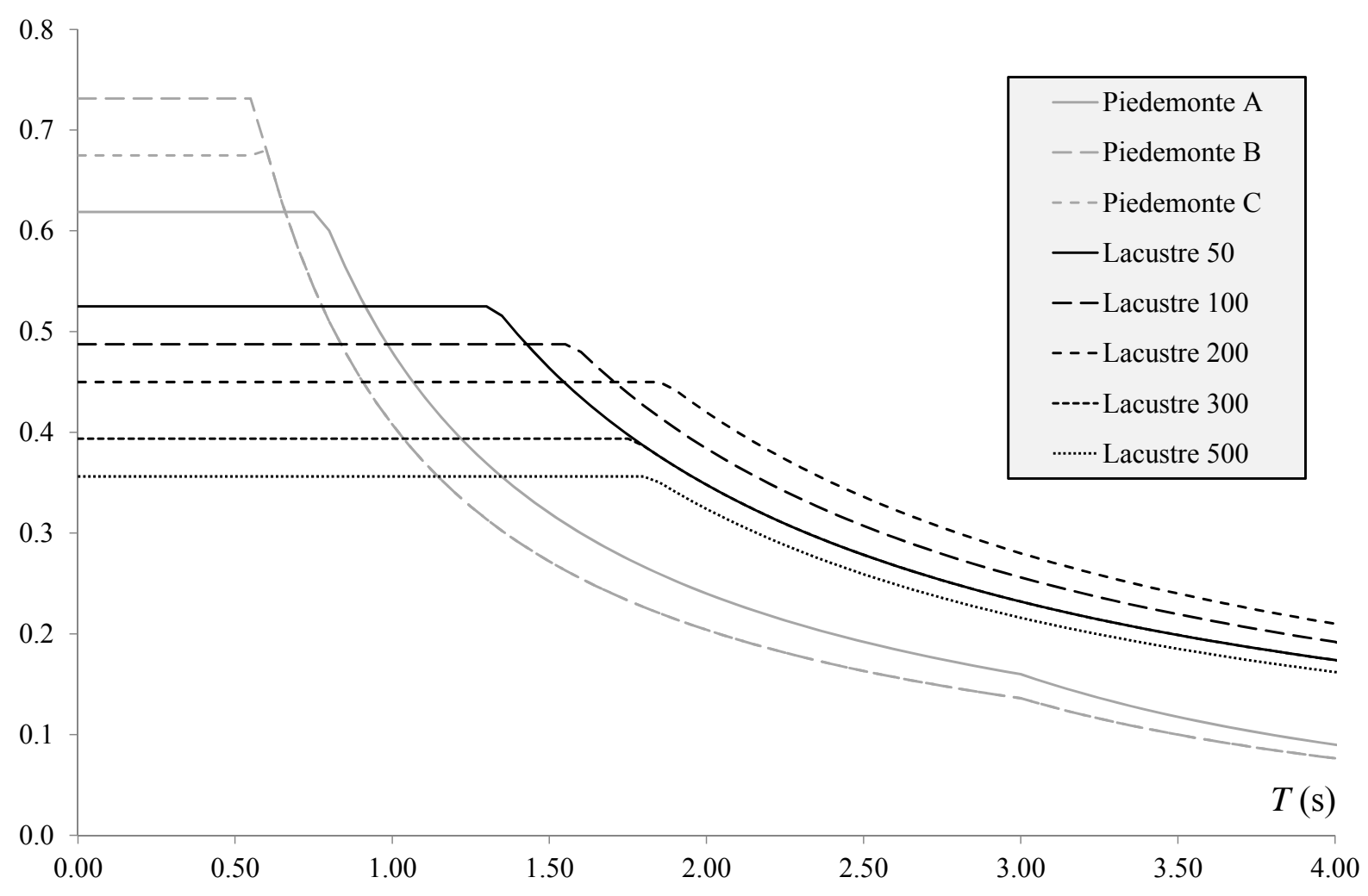

Figure 4. Design spectra according to the current seismic microzonation of Bogotá [2]

Comparison between Figure 2 and Figure 4 shows that in the former microzonation (Figure 2) the length of the plateau for soil "Lacustre A" is excessive; thus generating an overconservative spectrum.

\section{CONSIDERED BUILDINGS}

Eighteen prototype buildings are selected to represent the vast majority of the mid-height steel edifices in Bogotá. All these buildings have plan symmetry and are uniform along their height; all the columns are continuous down to foundation and the influence of the basements is neglected. The main carrying-load system is composed of steel columns and of steel decks topped with a concrete layer. The plan floor of the buildings is square, with four equal-length bays in each direction; there are $5 \times 5=25$ columns, which are laid according to an orthogonal regular pattern. The prototype buildings are distinguished by the span-length in both directions, by the number of floors and by the type of earthquake-resistant system (alike in both directions). Two span-lengths and three numbers of floors are considered: $6-8 \mathrm{~m}$ and 
$5-10-15$, respectively. Three earthquake-resistant systems have been considered: momentresistant frames (MRF), concentrically-braced frames (CBF) and eccentrically-braced frames (EBF); in these last two cases, chevron braces are contemplated. The cooperation of the infill walls (cladding and partitioning) is neglected since, according to the common construction practices in Colombia, they are habitually separated from the main structure. Figure 5 shows overall views of the structures of the selected prototype buildings. The structures depicted in Figure 5 correspond to MRF; CBF and EBF are similar, yet incorporating the chevron braces.

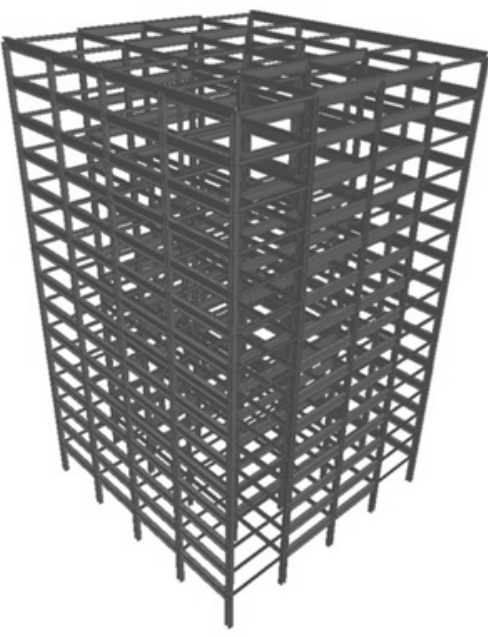

(b) 15-story buildings

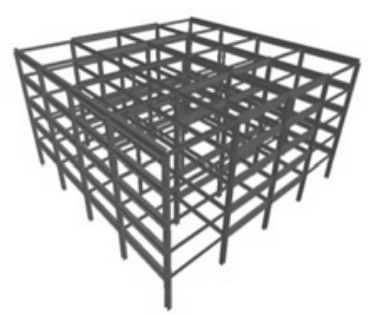

(a) 5-story buildings

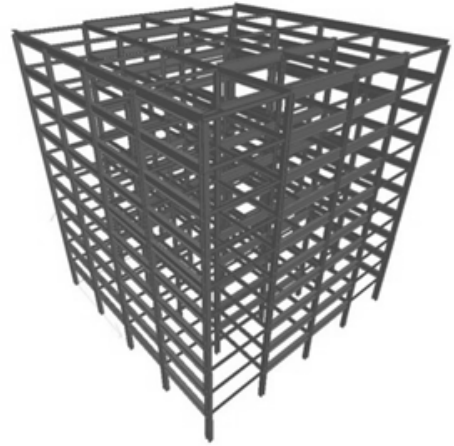

(c) 10-story buildings

Figure 5. Selected representative prototype buildings

As discussed previously, the structure of each of the eighteen prototypes buildings is designed for ten seismic zones in Bogotá; two of them (Figure 1, "Piedemonte" and "Lacustre A") correspond to the former microzonation and eight correspond to the current microzonation (Figure 3, "Piedemonte A, B and C" and "Lacustre 50, 100, 200, 300 and 500"). Therefore, the number of analyzed structures is $18 \times 10=180$.

To obtain representative results, the buildings in the two zones of the former microzonation have been designed according to the previous Colombian regulations [1]; conversely, the 
buildings in the eight zones of the current microzonation have been designed according to the current Colombian regulations [5]. The importance is "normal" (given their dwelling, administrative and commercial use). The seismic design is based in the simplified method stated in the codes; among other common simplifications, it implies assuming the same fundamental period in both directions (estimated from empirical expressions). In Bogotá the design acceleration is $A_{\mathrm{a}}=0.15 \mathrm{~g}$. The dead load has been assumed as $2.5 \mathrm{kN} / \mathrm{m}^{2}$ (slab selfweight $)+1.5 \mathrm{kN} / \mathrm{m}^{2}$ (partitioning walls) $+1 \mathrm{kN} / \mathrm{m}^{2}$ (facilities) $+1.5 \mathrm{kN} / \mathrm{m}^{2}$ (cladding system, distributed along the whole surface of the façade). Live load is $L=2 \mathrm{kN} / \mathrm{m}^{2}$; according to the Colombian code, $50 \%$ of this load is considered to act simultaneously with the seismic action. The design input spectra are obtained from the former and current microzonations, Figure 2 and Figure 4, respectively. In spite that the buildings are symmetric, $5 \%$ accidental eccentricities established by the [1] and the [5] are considered. The damping factor has been assumed equal to $5 \%$. The Colombian code states a design inter-story drift equal to $1 \%$; this condition is the most restrictive in most of the MRF buildings, being comparatively less restrictive in the $\mathrm{CBF}$ and EBF. The seismic design has consisted of determining equivalent static forces in both directions and applying them to 3D models of the structures of the buildings. As suggested by both Colombian regulations, only compact sections are selected for columns and beams [9].

The columns are made of A-572 steel $\left(f_{\mathrm{y}}=342 \mathrm{MPa}\right)[10]$ while the beams and joists are made of A-36 steel $\left(f_{\mathrm{y}}=248 \mathrm{MPa}\right)[11]$; this difference attempts getting earlier failures in the beams than in the columns. The compressive strength of the topping concrete is $f_{\mathrm{c}}{ }^{\prime}=21 \mathrm{MPa}$; the depth of the steel deck is $50+70 \mathrm{~mm}(120 \mathrm{~mm}$ concrete depth) and its thickness is 0.75 $\mathrm{mm}$. Figure 6 shows plan views of typical floor slabs of the selected buildings; Figure 6.a and Figure $6 . \mathrm{b}$ correspond to buildings with span-length equal to $6 \mathrm{~m}$ and to $8 \mathrm{~m}$, respectively. 
Figure 6 shows that each building contains two seismic-resistant frames in the $y$ direction (A and $\mathrm{E}$ frames) while in the $x$ direction there are four seismic-resistant frames (inside 1, 2, 4 and 5 frames). As discussed previously, each of these resistant parts can be either a momentresisting frame (MRF), a concentrically braced frame (CBF) or an eccentrically braced frame (EBF).

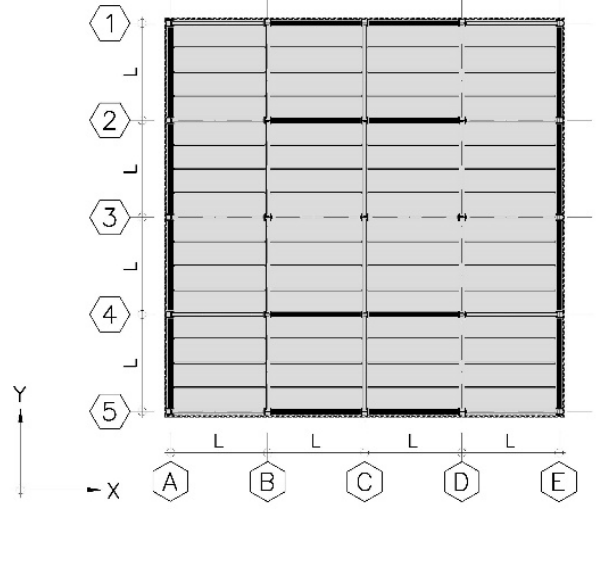

(a) $6 \times 6$ buildings $(L=6 \mathrm{~m})$

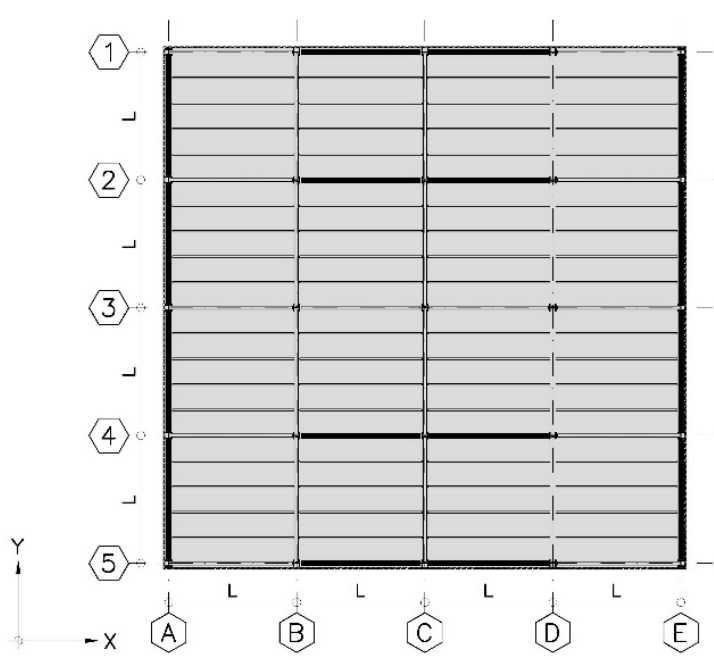

(b) $8 \times 8$ buildings $(L=8 \mathrm{~m})$

Figure 6. Floor slab layout

In the $6 \times 6$ buildings the height of the first floor is $4 \mathrm{~m}$ and the one of the upper floors is $3 \mathrm{~m}$; in the $8 \times 8$ buildings those heights are $4.50 \mathrm{~m}$ and $3.50 \mathrm{~m}$, respectively. As shown by Figure 6 , the separation in between the joists is $1.50 \mathrm{~m}(L / 4)$ for the $6 \times 6$ buildings and $1.60 \mathrm{~m}(L /$ 5) for the $8 \times 8$ buildings. The columns, beams and joists are made of W sections and the braces are made with square hollow sections (HSS) [9]. The joists are W10 $\times 15$ and W12 $\times 19$ for the $6 \times 6$ and $8 \times 8$ buildings, respectively. In the EBF buildings, the eccentricity between the chevron braces is selected for generating flexural-shear yielding failure in the link [12, 13]. Figure 7 shows overall elevation views of the selected 5-story buildings; the configurations of only some of the frames can be qualified as "seismic frames" (e.g. those designed to contribute to the lateral resistance); Figure 6 shows that, in the $x$ direction, there are four two-bay seismic frames (inner and outer frames, see Figure 7.a, Figure 7.c and Figure 7.e) and, in the $y$ direction, 
there are two four-bay seismic frames (outer frames, see Figure 7.b, Figure 7.d and Figure 7.f). In the seismic frames, the beam-column connections are pre-qualified according to [14]; the chosen type is "Welded Unreinforced Flange - Bolted Web" (WUF-B), commonly known as "California post-Northridge" connection. In the non-seismic frames, the beam-column connections are hinged. In the $\mathrm{CBF}$ and in the EBF the connections among the braces and the other members are hinged; as well as the connections among beams and columns. In the seismic frames, the columns are clamped to the foundation; otherwise, they are hinged. Shear studs connecting the steel deck with the supporting horizontal members are placed only in the nonseismic elements, e.g. the joists ( $y$ direction) and those beams that do not belong to the seismic frames ( $x$ and $y$ directions) $[15,16]$. This solution is customary in Bogotá and is basically intended for guaranteeing the diaphragm effect of the slabs (under lateral loading) rather than for increasing the bending stiffness and strength of beams and joists (under gravity loads). 


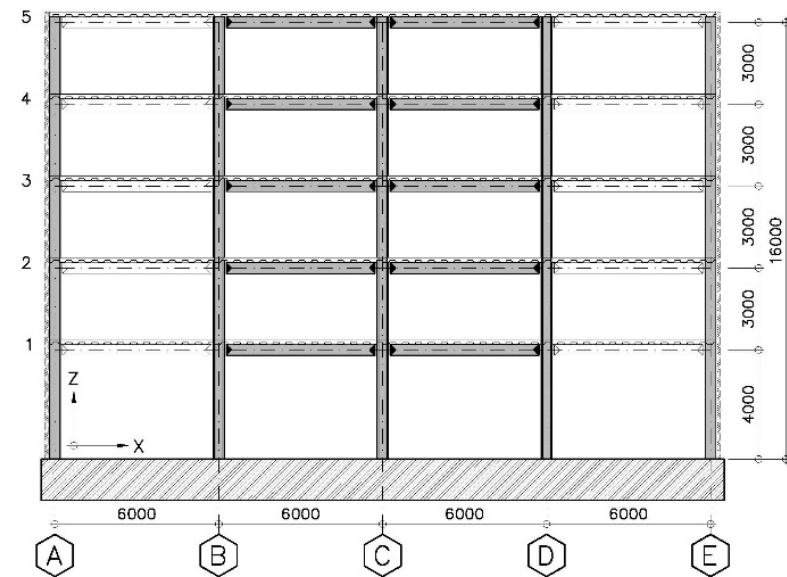

(a) MRF $x$ direction

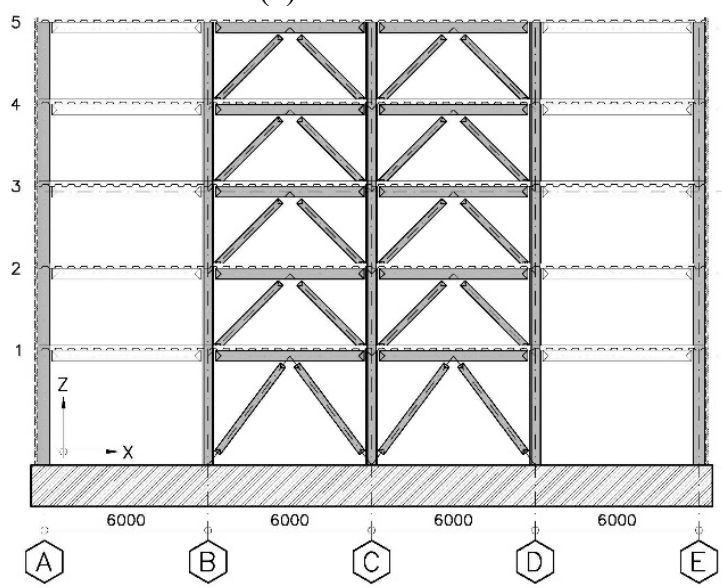

(c) $\mathrm{CBF} x$ direction

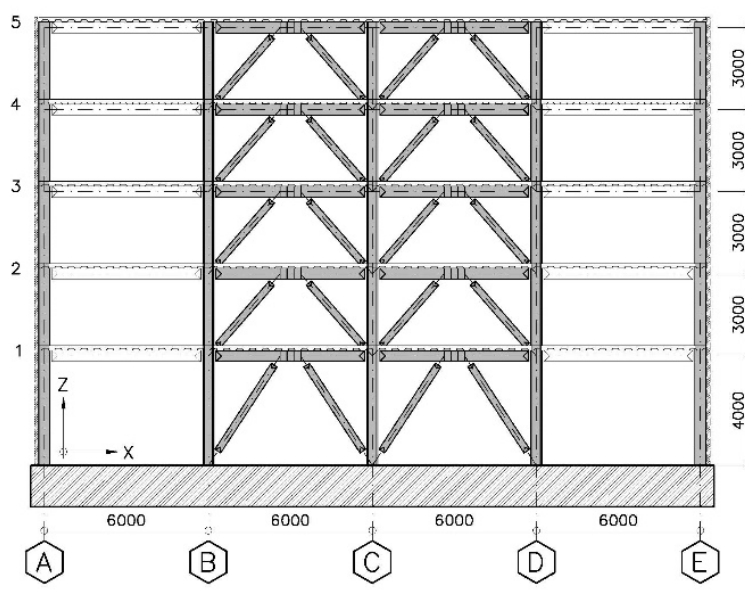

(e) EBF $x$ direction

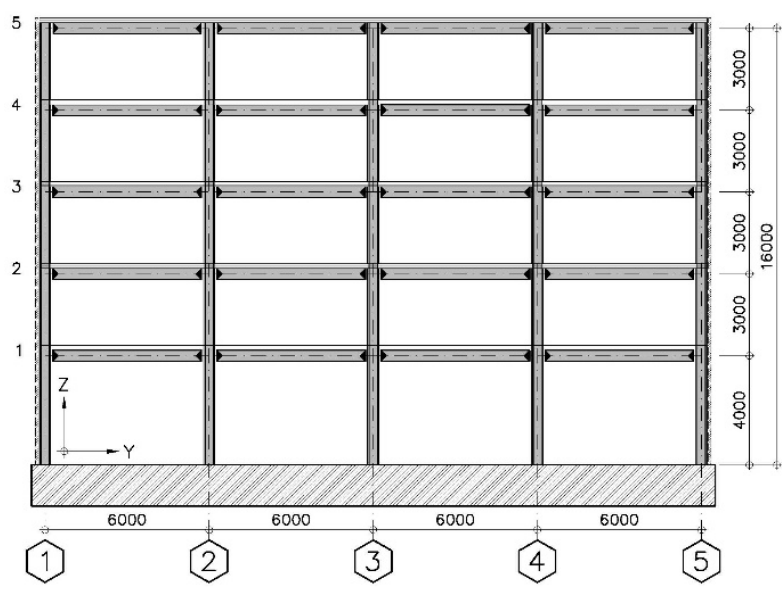

(b) MRF $y$ direction

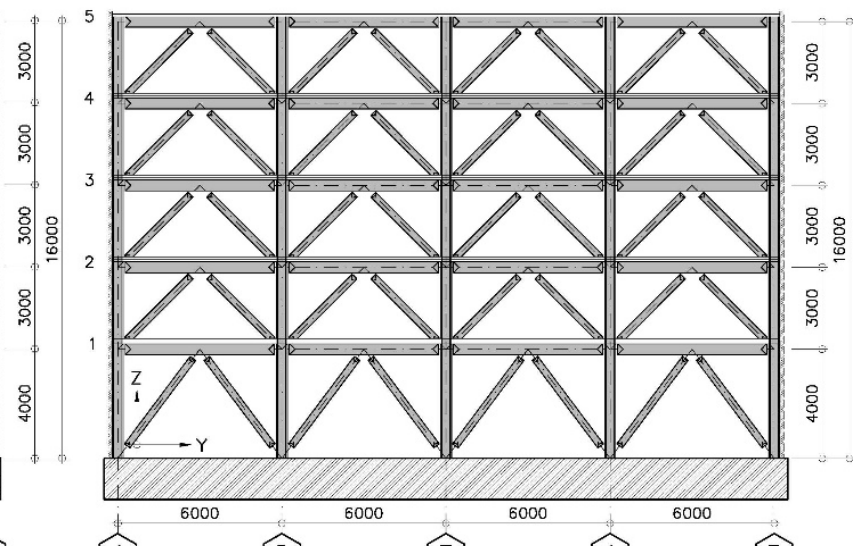

(2)

(3)

(4)

(5)

(d) $\mathrm{CBF} y$ direction

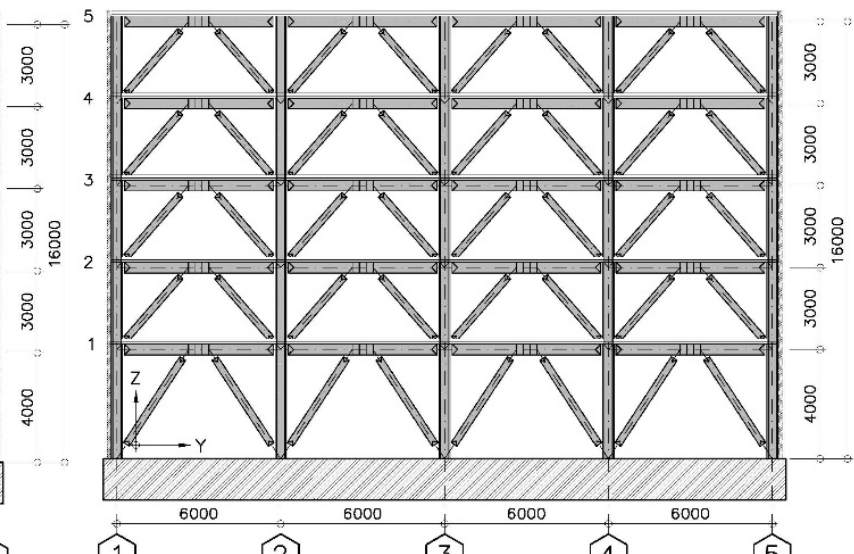

(f) EBF $y$ direction

Figure 7. Elevation views of the 5-story buildings

Table 1 displays the main structural features of each of the eighteen selected buildings. In the notation " $5-6 \times 6-$ MRF", " 5 " accounts for the number of stories, " $6 \times 6$ " refers to the spanlength in both directions (in m) and "MRF" means Moment-Resisting Frame; analogously "CBF" and "EBF" relate to Concentric-Braced Frames and to Eccentric-Braced Frames, 
respectively. Given that the structural parameters depend on the soil conditions, the properties in Table 1 correspond to the most demanding terrain "Piedemonte-B", as indicated in Figure 3. The steel profiles [9] belong to the seismic parts of the structure (highlighted members in Figure 6 and in Figure 7). The members of the structure have been designed according to the Colombian code [5] as "Moderate Energy Dissipation Capacity" for MRF and EBF and as “Special Energy Dissipation Capacity” for CBF; the recommendations in [12] and in [17] have been considered for EBF and CBF, respectively. In Table 1 there are two profiles per case, e.g. for building 5-6 $\times 6-$ MRF the first floor columns are W14×233 / W14 $\times 257$; the first / second profiles correspond to $x$ and $y$ directions, respectively. Noticeably, in the CBF the beams should be designed to resist the unbalanced axial forces transmitted by the braces after the buckling of the compressed brace $[5,17]$; Table 1 shows that the beams of the CBF are significantly stiffer than those of EBF and even of CBF. In the EBF the braces are designed not to buckle prior to the formation of plastic hinges in the link [12]. 
Table 1. Representative prototype buildings as designed for the "Piedemonte B" zone (newer microzonation)

\begin{tabular}{|c|c|c|c|c|c|c|}
\hline Building & $\begin{array}{l}\text { First floor } \\
\text { beams }\left(^{*}\right)\end{array}$ & $\begin{array}{l}\text { Top floor } \\
\text { beams }(*)\end{array}$ & $\begin{array}{c}\text { First floor } \\
\left.\text { columns( }{ }^{*}\right)\end{array}$ & $\begin{array}{c}\text { Top floor } \\
\text { columns }\left(^{*}\right)\end{array}$ & $\begin{array}{c}\text { First floor } \\
\text { braces }\end{array}$ & $\begin{array}{c}\text { Top floor } \\
\text { braces }\end{array}$ \\
\hline $\begin{array}{c}5-6 \times 6- \\
\text { MRF }\end{array}$ & $\begin{array}{l}\text { W21×132/ } \\
W 21 \times 147\end{array}$ & $\begin{array}{l}\text { W21×83/ } \\
W 21 \times 73\end{array}$ & $\begin{array}{l}\text { W14×233 / } \\
\text { W14×257 }\end{array}$ & $\begin{array}{l}\text { W14×145 / } \\
\text { W14×132 }\end{array}$ & - & - \\
\hline $\begin{array}{c}5-8 \times 8- \\
\mathrm{MRF}\end{array}$ & $\begin{array}{l}\text { W30×191/ } \\
W 30 \times 211\end{array}$ & $\begin{array}{l}\text { W21×132/ } \\
\text { W21×132 }\end{array}$ & $\begin{array}{l}\text { W14×342 / } \\
W 14 \times 370\end{array}$ & $\begin{array}{l}\text { W14×233 / } \\
\text { W14×233 }\end{array}$ & - & - \\
\hline $\begin{array}{c}5-6 \times 6- \\
\mathrm{CBF}\end{array}$ & $\begin{array}{l}\text { W27×161/ } \\
W 30 \times 173\end{array}$ & $\begin{array}{l}\text { W27×146/ } \\
\text { W27×161 }\end{array}$ & $\begin{array}{l}\text { W14×159/ } \\
W 14 \times 211\end{array}$ & W14×53 / W14×43 & HSS5" $\times 1 / 2 "$ & HSS4" ×1/2" \\
\hline $\begin{array}{c}5-8 \times 8- \\
\mathrm{CBF}\end{array}$ & $\begin{array}{l}\text { W30×261 / } \\
\text { W30×292 }\end{array}$ & $\begin{array}{l}\text { W30×211 / } \\
\text { W30×191 }\end{array}$ & $\begin{array}{l}\text { W14×398 / } \\
W 14 \times 370\end{array}$ & $\begin{array}{l}\text { W14×193/ } \\
\text { W14×176 }\end{array}$ & HSS6" $\times 1 / 2 "$ & HSS6" ${ }^{\prime 3} / 8 "$ \\
\hline $\begin{array}{c}5-6 \times 6- \\
\mathrm{EBF}\end{array}$ & $\begin{array}{l}\mathrm{W} 12 \times 40 / \\
\mathrm{W} 12 \times 45\end{array}$ & $\begin{array}{l}\mathrm{W} 12 \times 26 / \\
\mathrm{W} 12 \times 26\end{array}$ & $\begin{array}{l}\mathrm{W} 12 \times 87 / \\
\mathrm{W} 12 \times 58\end{array}$ & $\mathrm{~W} 12 \times 35$ / W12×26 & HSS5" $\times 1 / 2 "$ & HSS4" $\times 3 / 16 "$ \\
\hline $\begin{array}{c}5-8 \times 8- \\
\mathrm{EBF}\end{array}$ & $\begin{array}{l}\mathrm{W} 16 \times 50 / \\
\mathrm{W} 16 \times 57\end{array}$ & $\begin{array}{l}\mathrm{W} 16 \times 36 / \\
\mathrm{W} 16 \times 36\end{array}$ & $\begin{array}{c}\mathrm{W} 12 \times 136 / \\
\mathrm{W} 12 \times 65\end{array}$ & $\mathrm{~W} 12 \times 53$ / W12×30 & HSS6" $\times 1 / 2 "$ & HSS6" $\times 3 / 8 "$ \\
\hline $\begin{array}{c}10-6 \times 6- \\
M R F\end{array}$ & $\begin{array}{l}\text { W27×161/ } \\
W 27 \times 178\end{array}$ & $\begin{array}{l}\mathrm{W} 18 \times 35 / \\
\mathrm{W} 18 \times 35\end{array}$ & $\begin{array}{l}\text { W14×257 / } \\
\text { W14×257 }\end{array}$ & $\mathrm{W} 10 \times 54$ / W10×54 & - & - \\
\hline $\begin{array}{c}10-8 \times 8- \\
\mathrm{MRF}\end{array}$ & $\begin{array}{l}\text { W33×241 / } \\
\text { W33×241 }\end{array}$ & $\begin{array}{l}\text { W21×147 / } \\
\text { W21×147 }\end{array}$ & $\begin{array}{l}\text { W14×398 / } \\
\text { W14×426 }\end{array}$ & $\begin{array}{l}\text { W14×252/ } \\
\text { W14×252 }\end{array}$ & - & - \\
\hline $\begin{array}{c}10-6 \times 6- \\
\mathrm{CBF}\end{array}$ & $\begin{array}{l}\text { W33×263 / } \\
W 33 \times 263\end{array}$ & $\begin{array}{l}\text { W33×118/ } \\
\text { W33×118 }\end{array}$ & $\begin{array}{l}\mathrm{W} 14 \times 455 / \\
\mathrm{W} 14 \times 370\end{array}$ & $\begin{array}{c}\mathrm{W} 14 \times 109 / \\
\mathrm{W} 14 \times 61\end{array}$ & HSS6" $\times 1 / 2 "$ & HSS6" $\times 3 / 16 "$ \\
\hline $\begin{array}{c}10-8 \times 8- \\
\mathrm{CBF}\end{array}$ & $\begin{array}{l}\text { W36×328 / } \\
\text { W36×328 }\end{array}$ & $\begin{array}{l}\text { W36×170 / } \\
\text { W36×170 }\end{array}$ & $\begin{array}{l}\text { W14×550 / } \\
W 14 \times 455\end{array}$ & $\begin{array}{l}\text { W14×120 / } \\
W 14 \times 120\end{array}$ & $\begin{array}{c}\mathrm{HSS} 10 " \times 5 / 8 \\
, "\end{array}$ & HSS10"×1/4" \\
\hline $\begin{array}{c}10-6 \times 6- \\
\mathrm{EBF}\end{array}$ & $\begin{array}{l}\text { W14×38 / } \\
\text { W14×48 }\end{array}$ & $\begin{array}{l}\mathrm{W} 14 \times 22 / \\
\mathrm{W} 14 \times 30\end{array}$ & $\begin{array}{l}\text { W14×176/ } \\
\text { W14×109 }\end{array}$ & $\begin{array}{c}\mathrm{W} 14 \times 120 / \\
\mathrm{W} 14 \times 74\end{array}$ & $\operatorname{HSS} 5 " \times 3 / 8 "$ & HSS $41 / 2 " \times 3 / 16 "$ \\
\hline $\begin{array}{c}10-8 \times 8- \\
\mathrm{EBF}\end{array}$ & $\begin{array}{l}\mathrm{W} 16 \times 50 / \\
\mathrm{W} 16 \times 67\end{array}$ & $\begin{array}{l}\mathrm{W} 16 \times 31 / \\
\mathrm{W} 16 \times 40 \\
\end{array}$ & $\begin{array}{l}\text { W14×283 / } \\
W 14 \times 145\end{array}$ & $\begin{array}{c}\mathrm{W} 14 \times 193 / \\
\mathrm{W} 14 \times 99\end{array}$ & HSS6" $\times 5 / 8 "$ & HSS6"×1/4" \\
\hline $\begin{array}{c}15-6 \times 6- \\
M R F\end{array}$ & $\begin{array}{l}\text { W30×191/ } \\
\text { W30×191 }\end{array}$ & $\begin{array}{l}\text { W24×104 / } \\
\text { W24×104 }\end{array}$ & $\begin{array}{c}\text { W14×311 / } \\
\text { W14×311 }\end{array}$ & $\begin{array}{l}\text { W14×176/ } \\
\text { W14×176 }\end{array}$ & - & - \\
\hline $\begin{array}{c}15-8 \times 8- \\
M R F\end{array}$ & $\begin{array}{l}\text { W36×260 / } \\
\text { W36×280 }\end{array}$ & $\begin{array}{l}\text { W27×161/ } \\
\text { W30×173 }\end{array}$ & $\begin{array}{l}\text { W14×455 / } \\
W 14 \times 455\end{array}$ & $\begin{array}{l}\text { W14×283 / } \\
\text { W14×283 }\end{array}$ & - & - \\
\hline $\begin{array}{c}15-6 \times 6- \\
\mathrm{CBF}\end{array}$ & $\begin{array}{l}\text { W36×280/ } \\
\text { W36×260 }\end{array}$ & $\begin{array}{l}\text { W36×182 / } \\
\text { W36×170 }\end{array}$ & $\begin{array}{l}\mathrm{W} 14 \times 605 / \\
\mathrm{W} 14 \times 500\end{array}$ & $\begin{array}{l}\text { W14×211/ } \\
\text { W14×176 }\end{array}$ & HSS7" $\times 5 / 8 "$ & HSS6" $x^{3} / 16 "$ \\
\hline $\begin{array}{c}15-8 \times 8- \\
\mathrm{CBF}\end{array}$ & $\begin{array}{l}\text { W36×529 / } \\
\text { W36×441 }\end{array}$ & $\begin{array}{l}\text { W36×328 / } \\
\text { W36×280 }\end{array}$ & $\begin{array}{l}\text { W14×655 / } \\
W 14 \times 550\end{array}$ & $\begin{array}{l}\text { W14×311/ } \\
\text { W14×211 }\end{array}$ & HSS9" $\times 5 / 8 "$ & HSS8"×1/1/4" \\
\hline $\begin{array}{c}15-6 \times 6- \\
\mathrm{EBF}\end{array}$ & $\begin{array}{l}\text { W14×61 / } \\
\text { W14×61 }\end{array}$ & $\begin{array}{l}\text { W14×26/ } \\
W 14 \times 30\end{array}$ & $\begin{array}{l}\text { W14×257 / } \\
\text { W14×159 }\end{array}$ & $\begin{array}{c}\mathrm{W} 14 \times 145 / \\
\mathrm{W} 14 \times 90\end{array}$ & HSS6" $\times 3 / 8 "$ & HSS5" $x^{3} / 16 "$ \\
\hline $\begin{array}{c}15-8 \times 8- \\
\mathrm{EBF}\end{array}$ & $\begin{array}{l}\text { W16×67 / } \\
\text { W16×89 }\end{array}$ & $\begin{array}{l}\mathrm{W} 16 \times 31 / \\
\mathrm{W} 16 \times 40\end{array}$ & $\begin{array}{c}\mathrm{W} 14 \times 426 \\
\mathrm{~W} 14 \times 233\end{array}$ & $\begin{array}{l}\text { W14×257 / } \\
\text { W14×132 }\end{array}$ & HSS7" $\times 5 / 8 "$ & HSS6" $\times 5 / 16 "$ \\
\hline
\end{tabular}

$\left(^{*}\right)$ The first / second profiles correspond to $x$ and $y$ directions, respectively. 
Table 2 displays the main seismic design parameters for the representative prototype buildings, for the "Piedemonte B" zone (NSR-10, newer microzonation). The weights correspond to the dead load. The fundamental periods $T_{0}$ have been determined from the empirical expressions suggested by the [5]. The fundamental periods in both directions $\left(T_{0 \mathrm{x}}\right.$ and $\left.T_{0 y}\right)$ have been also obtained from linear elastic modal analyses by using the same structural modeling than in the push-over analyses (section 4); since the modal analyses are linear, the obtained fundamental periods refer to initial (undamaged) conditions. The comparison among the values of $T_{0}$ and $T_{0 \mathrm{x}}$ and $T_{0 \mathrm{y}}$ shows no major differences among them. The fundamental periods $T_{\mathrm{F}}$ listed in Table 2 show that the initial stiffness in both directions is similar; comparison among the $\mathrm{MRF}, \mathrm{CBF}$ and $\mathrm{EBF}$ cases shows that the stiffening generated by the braces is important, mostly in the concentrically-braced buildings. As well, the buildings spanning $6 \mathrm{~m}$ are significantly stiffer than those spanning $8 \mathrm{~m}$. The response reduction factor $(R)$ is obtained as indicated in the [5]. Last two columns in Table 2 show the dimensionless spectral ordinates $S_{\mathrm{a}} / A_{\mathrm{a}}$ where $A_{\mathrm{a}}=0.15 \mathrm{~g}$, as discussed previously. Figure 4 shows that the constant-acceleration branch of the design spectrum ranges in between $T=0$ and $T_{\mathrm{C}}=0.56 \mathrm{~s}$; therefore, only buildings $5-6 \times 6-\mathrm{CBF}, 5-8 \times 8-\mathrm{CBF}$ and $5-6 \times 6-$ EBF lay inside the plateau. The amplification factors accounting for the current microzonation are $F_{\mathrm{a}}=1.95$ and $F_{\mathrm{v}}=1.70[2,5]$. The important values of $S_{\mathrm{a}} / A_{\mathrm{a}}$ in the last two columns in Table 2 show that the input acceleration in the bedrock is significantly amplified in the top of the buildings; in the 5-story buildings this effect is contributed both by the soft soil and by the rather stiff building. 
Table 2. Design parameters for the prototype representative buildings. "Piedemonte B" zone (newer microzonation [2])

\begin{tabular}{cccccccc}
\hline Building & Weight $(\mathrm{kN})$ & $T_{0}(\mathrm{~s})$ & $T_{0 \mathrm{x}}(\mathrm{s})$ & $T_{0 \mathrm{y}}(\mathrm{s})$ & $R$ & $S_{\mathrm{a}} / A_{\mathrm{a}}(x)$ & $S_{\mathrm{a}} / A_{\mathrm{a}}(y)$ \\
\hline $5-6 \times 6-\mathrm{MRF}$ & 17285 & 0.627 & 0.662 & 0.629 & 4.5 & 4.109 & 4.324 \\
$5-8 \times 8-\mathrm{MRF}$ & 29429 & 0.726 & 0.743 & 0.706 & 4.5 & 3.660 & 3.853 \\
$5-6 \times 6-\mathrm{CBF}$ & 17285 & 0.362 & 0.392 & 0.372 & 4.5 & 4.873 & 4.873 \\
$5-8 \times 8-\mathrm{CBF}$ & 29429 & 0.421 & 0.437 & 0.415 & 4.5 & 4.873 & 4.873 \\
$5-6 \times 6-\mathrm{EBF}$ & 17285 & 0.523 & 0.584 & 0.555 & 5.4 & 4.658 & 4.873 \\
$5-8 \times 8-\mathrm{EBF}$ & 29429 & 0.621 & 0.651 & 0.618 & 5.4 & 4.178 & 4.401 \\
\hline $10-6 \times 6-\mathrm{MRF}$ & 34496 & 1.215 & 1.123 & 1.067 & 4.5 & 2.422 & 2.549 \\
$10-8 \times 8-\mathrm{MRF}$ & 58760 & 1.211 & 1.266 & 1.203 & 4.5 & 2.148 & 2.261 \\
$10-6 \times 6-\mathrm{CBF}$ & 34496 & 0.635 & 0.644 & 0.611 & 4.5 & 4.224 & 4.452 \\
$10-8 \times 8-\mathrm{CBF}$ & 58760 & 0.717 & 0.720 & 0.684 & 4.5 & 3.778 & 3.977 \\
$10-6 \times 6-\mathrm{EBF}$ & 34496 & 1.001 & 0.959 & 0.911 & 5.4 & 2.836 & 2.986 \\
$10-8 \times 8-\mathrm{EBF}$ & 58760 & 1.173 & 1.073 & 1.019 & 5.4 & 2.608 & 2.669 \\
\hline $15-6 \times 6-\mathrm{MRF}$ & 51707 & 1.525 & 1.540 & 1.463 & 4.5 & 1.763 & 1.859 \\
$15-8 \times 8-\mathrm{MRF}$ & 88091 & 1.726 & 1.738 & 1.651 & 4.5 & 1.565 & 1.647 \\
$15-6 \times 6-\mathrm{CBF}$ & 51707 & 0.816 & 0.865 & 0.822 & 4.5 & 3.145 & 3.309 \\
$15-8 \times 8-\mathrm{CBF}$ & 88091 & 0.972 & 0.969 & 0.921 & 4.5 & 2.807 & 2.953 \\
$15-6 \times 6-\mathrm{EBF}$ & 51707 & 1.287 & 1.289 & 1.222 & 5.4 & 2.110 & 2.226 \\
$15-8 \times 8-\mathrm{EBF}$ & 88091 & 1.424 & 1.444 & 1.372 & 5.4 & 1.884 & 1.983 \\
\hline
\end{tabular}

Table 3 displays the equivalent modal masses $\left(m_{i}^{*}\right)$ expressed in terms of the total mass of the building $(m)$. Figures from Table 3 provide the following conclusions regarding the relative importance of the first modes: (i) there are no relevant differences between the $x$ and $y$ directions and between the $6 \times 6$ and $8 \times 8$ buildings and (ii) except for CBF, the first modal masses of the lower modes are higher for shorter buildings. Results from Table 3 show that in practically all the cases the modal masses of the first mode are higher than $75 \%$ of the mass of the building; in this case, the FEMA 356 Prestandard and the ASCE-41 [18, 19] indicate that, in the push-over analyses, the variation of the horizontal pushing forces along the height of the building is proportional to the coefficient given by equation 3-12 of that code. Such coefficient is proportional to the mass of each floor and to the height from the base of the building. 
Table 3. Modal masses participation factors. "Piedemonte B" zone (newer microzonation)

\begin{tabular}{|c|c|c|c|c|c|c|c|c|c|c|}
\hline Building & $\begin{array}{c}m_{1} * / \\
m\end{array}$ & $\begin{array}{c}m_{2} * / \\
m\end{array}$ & $\begin{array}{c}\text { direction } \\
m_{3} * / \\
m\end{array}$ & $\begin{array}{c}m 4^{*} / \\
m\end{array}$ & $\begin{array}{c}m_{5} * / \\
m\end{array}$ & $\begin{array}{c}m_{1} * / \\
m\end{array}$ & $\begin{array}{c}m_{2} * / \\
m\end{array}$ & $\begin{array}{c}\text { direction } \\
m_{3} * / \\
m\end{array}$ & $\begin{array}{c}m_{4}^{*} / \\
m\end{array}$ & $\begin{array}{c}m_{5} * / \\
m\end{array}$ \\
\hline $5-6 \times 6-\mathrm{MRF}$ & 0.8570 & 0.1040 & 0.0286 & 0.0078 & 0.0026 & 0.8503 & 0.1105 & 0.0285 & 0.0083 & 0.0024 \\
\hline $5-8 \times 8-\mathrm{MRF}$ & 0.8637 & 0.1019 & 0.0307 & 0.0059 & 0.0019 & 0.8812 & 0.0897 & 0.0276 & 0.0076 & 0.0017 \\
\hline $5-6 \times 6-\mathrm{CBF}$ & 0.7664 & 0.1117 & 0.0426 & 0.0211 & 0.0124 & 0.7152 & 0.1038 & 0.0424 & 0.0204 & 0.0112 \\
\hline $5-8 \times 8-\mathrm{CBF}$ & 0.7254 & 0.1245 & 0.0503 & 0.0246 & 0.0115 & 0.7343 & 0.1124 & 0.0325 & 0.0223 & 0.0113 \\
\hline $5-6 \times 6-\mathrm{EBF}$ & 0.8723 & 0.0984 & 0.0189 & 0.0077 & 0.0027 & 0.8804 & 0.0950 & 0.0157 & 0.0068 & 0.0021 \\
\hline $5-8 \times 8-\mathrm{EBF}$ & 0.8762 & 0.0953 & 0.0184 & 0.0074 & 0.0028 & 0.8867 & 0.0905 & 0.0158 & 0.0053 & 0.0018 \\
\hline $\begin{array}{c}10-6 \times 6- \\
\text { MRF }\end{array}$ & 0.8042 & 0.1117 & 0.0426 & 0.0021 & 0.0011 & 0.8156 & 0.1038 & 0.0424 & 0.0020 & 0.0010 \\
\hline $\begin{array}{c}10-8 \times 8- \\
\text { MRF }\end{array}$ & 0.8201 & 0.1245 & 0.0503 & 0.0020 & 0.0007 & 0.8347 & 0.1124 & 0.0325 & 0.0016 & 0.0012 \\
\hline $\begin{array}{c}10-6 \times 6- \\
\mathrm{CBF}\end{array}$ & 0.7723 & 0.1684 & 0.0325 & 0.0225 & 0.0128 & 0.7857 & 0.1107 & 0.0540 & 0.0218 & 0.0122 \\
\hline $\begin{array}{c}10-8 \times 8- \\
\mathrm{CBF}\end{array}$ & 0.7842 & 0.1722 & 0.0364 & 0.0203 & 0.0118 & 0.7962 & 0.1134 & 0.0410 & 0.0254 & 0.0124 \\
\hline $\begin{array}{c}10-6 \times 6- \\
\text { EBF }\end{array}$ & 0.8132 & 0.1224 & 0.0326 & 0.0153 & 0.0075 & 0.8295 & 0.1157 & 0.0315 & 0.0118 & 0.0054 \\
\hline $\begin{array}{c}10-8 \times 8- \\
\text { EBF }\end{array}$ & 0.8117 & 0.1192 & 0.0354 & 0.0154 & 0.0080 & 0.8199 & 0.1229 & 0.0321 & 0.0126 & 0.0056 \\
\hline $\begin{array}{c}15-6 \times 6- \\
\text { MRF }\end{array}$ & 7625 & .1283 & 0357 & .0022 & 0.0009 & .7746 & 0.1203 & 0.0540 & 0.0024 & 0.0007 \\
\hline $\begin{array}{c}15-8 \times 8- \\
\text { MRF }\end{array}$ & 0.7753 & 0.1321 & 0.0420 & 0.0019 & 0.0011 & 0.7881 & 0.1229 & 0.0410 & 0.0018 & 0.0011 \\
\hline $\begin{array}{c}15-6 \times 6- \\
\mathrm{CBF}\end{array}$ & 0.7373 & 0.1626 & 0.0455 & 0.0217 & 0.0133 & 0.7767 & 0.1183 & 0.0513 & 0.0190 & 0.0127 \\
\hline $\begin{array}{c}15-8 \times 8- \\
\mathrm{CBF}\end{array}$ & 0.7445 & 0.1642 & 0.0459 & 0.2190 & 0.0112 & 0.7840 & 0.1195 & 0.0518 & 0.0192 & 0.0124 \\
\hline $\begin{array}{c}15-6 \times 6- \\
\text { EBF }\end{array}$ & 0.7659 & 0.1381 & 0.0475 & 0.0184 & 0.0109 & 0.7874 & 0.1283 & 0.0436 & 0.0167 & 0.0094 \\
\hline $\begin{array}{c}15-8 \times 8- \\
\text { EBF }\end{array}$ & 0.7769 & 0.1292 & 0.0421 & 0.0208 & 0.0106 & 0.7607 & 0.1480 & 0.0456 & 0.0195 & 0.0099 \\
\hline
\end{tabular}

Table 4 displays the structural steel weight of the eighteen prototype buildings whose structure has been designed for the aforementioned ten seismic zones (Figure 2 and Figure 4). This weight comprises the main structural steel members: columns, beams, braces, base and gusset plates, stiffener plates, bolts and welds. Broadly speaking, the overall cost of the structure is proportional to that weight; however, the unit cost of the braced frames might be slightly higher than the one of the MRF due to the influence of the detailing of the connections. Figures from Table 4 show that the eccentrically braced frames have significantly less lightweight than the moment resisting frames and that the concentrically braced frames. 
Table 4. Structural steel weight $(\mathrm{kN})$

\begin{tabular}{|c|c|c|c|c|c|c|c|c|c|c|}
\hline \multirow[b]{2}{*}{ Building } & \multicolumn{2}{|c|}{ NSR-98 } & \multirow[b]{2}{*}{$\begin{array}{c}\text { Pied. } \\
\text { A }\end{array}$} & \multirow[b]{2}{*}{$\begin{array}{c}\text { Pied. } \\
\text { B }\end{array}$} & \multicolumn{4}{|c|}{ NSR-10 } & \multirow[b]{2}{*}{$\begin{array}{l}\text { Lac. } \\
300\end{array}$} & \multirow[b]{2}{*}{$\begin{array}{c}\text { Lac. } \\
500\end{array}$} \\
\hline & Pied. & Lac. A & & & $\begin{array}{c}\text { Pied. } \\
\text { C }\end{array}$ & $\begin{array}{c}\text { Lac. } \\
50\end{array}$ & $\begin{array}{c}\text { Lac. } \\
100\end{array}$ & $\begin{array}{c}\text { Lac. } \\
200\end{array}$ & & \\
\hline $5-6 \times 6-\mathrm{MRF}$ & 2776 & 2628 & 2597 & 2597 & 2597 & 2335 & 2221 & 2140 & 1941 & 1858 \\
\hline $5-8 \times 8-\mathrm{MRF}$ & 5584 & 5047 & 5042 & 4843 & 4843 & 4546 & 4475 & 4350 & 4020 & 3809 \\
\hline $5-6 \times 6-\mathrm{CBF}$ & 4131 & 3451 & 2679 & 2841 & 2661 & 2365 & 2123 & 1960 & 1811 & 1653 \\
\hline $5-8 \times 8-\mathrm{CBF}$ & 5992 & 4838 & 5517 & 6085 & 6012 & 5192 & 5043 & 5120 & 4940 & 4654 \\
\hline $5-6 \times 6-\mathrm{EBF}$ & 1496 & 1338 & 1344 & 1408 & 1395 & 1288 & 1278 & 1235 & 1215 & 1196 \\
\hline $5-8 \times 8-\mathrm{EBF}$ & 2680 & 2484 & 2498 & 2498 & 2498 & 2344 & 2406 & 2339 & 2276 & 2263 \\
\hline $10-6 \times 6-\mathrm{MRF}$ & 8213 & 7363 & 5926 & 5533 & 5533 & 6696 & 6408 & 6145 & 5933 & 5533 \\
\hline $10-8 \times 8-\mathrm{MRF}$ & 16719 & 16108 & 11687 & 10989 & 10989 & 14252 & 13489 & 13039 & 12163 & 11227 \\
\hline $10-6 \times 6-\mathrm{CBF}$ & 7913 & 6938 & 7564 & 7937 & 7937 & 6359 & 6259 & 5902 & 5656 & 5121 \\
\hline $10-8 \times 8-\mathrm{CBF}$ & 16503 & 14456 & 14391 & 13417 & 13417 & 12407 & 11922 & 11442 & 10527 & 10084 \\
\hline $10-6 \times 6-\mathrm{EBF}$ & 4100 & 3698 & 3549 & 3546 & 3414 & 3593 & 3446 & 3449 & 3267 & 3041 \\
\hline $10-8 \times 8-\mathrm{EBF}$ & 7710 & 7169 & 6857 & 6479 & 6479 & 7406 & 6987 & 6987 & 6464 & 6408 \\
\hline $15-6 \times 6-\mathrm{MRF}$ & 14545 & 15619 & 9871 & 9187 & 9187 & 12162 & 12743 & 12195 & 11437 & 9837 \\
\hline $15-8 \times 8-\mathrm{MRF}$ & 29697 & 34828 & 19357 & 17307 & 17307 & 24540 & 26291 & 26291 & 24540 & 22793 \\
\hline $15-6 \times 6-\mathrm{CBF}$ & 16390 & 14236 & 16252 & 14108 & 14108 & 14701 & 15654 & 13446 & 12939 & 10830 \\
\hline $15-8 \times 8-\mathrm{CBF}$ & 37651 & 33822 & 33112 & 26707 & 28988 & 35979 & 32774 & 29953 & 28217 & 26037 \\
\hline $15-6 \times 6-\mathrm{EBF}$ & 10728 & 9079 & 6668 & 6262 & 6250 & 7812 & 7316 & 6954 & 6499 & 6128 \\
\hline $15-8 \times 8-\mathrm{EBF}$ & 15565 & 13996 & 12455 & 11615 & 11615 & 14083 & 14083 & 13736 & 14895 & 12621 \\
\hline
\end{tabular}

\section{NUMERICAL MODELLING OF THE STRUCTURAL BEHAVIOR}

For the push-over analyses, the structural behavior of the selected buildings (section 3 ) is described with 2-D finite element models with frame elements [20]. Each push-over analysis is carried out in a single frame; the cooperation of the non-seismic frames is neglected, hence, as shown by Figure 6, there are four seismic frames in $x$ direction and 2 in $y$ direction. In the $x$ direction, the outer and inner frames are considered alike, despite the minor differences among them, mainly the supported load. Given the absence of shear studs in the seismic frames (see section 3), the cooperation of the top concrete layer is neglected.

- MRF buildings. In the MRF buildings the behavior of beams and columns is considered basically linear while the nonlinearities are concentrated in plastic hinges located near the beam-column connections.

- CBF buildings. In the CBF buildings [21, 22] the first failure arises when the compressed braces reach their critical buckling forces, accounting for the initial imperfections; once these braces buckle they are disengaged from the main frame, without any residual afterbuckling strength. The braces have been conservatively considered hinged in both 
transverse directions. This brittle collapse model involves a simplification on the safe side.

- EBF buildings. In the EBF buildings the behavior of beams and columns is considered basically linear while the nonlinearities are concentrated in plastic hinges located in the connections between the braces and the main beams.

Figure 8 describes the aforementioned failure mechanisms for $\mathrm{MRF}, \mathrm{CBF}$ and $\mathrm{EBF}$.

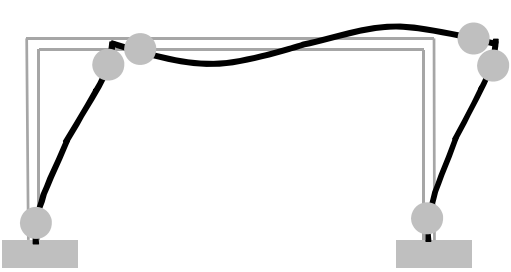

(a) MRF

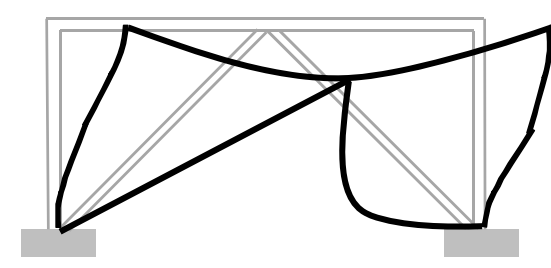

(b) $\mathrm{CBF}$

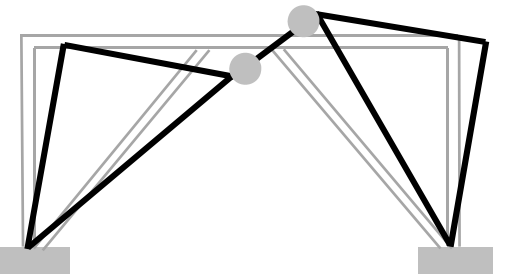

(c) $\mathrm{EBF}$

Figure 8. Failure mechanisms for the considered building types

The hysteretic behavior of the plastic hinges is described by multi-linear moment-curvature laws, as the one displayed by Figure 9. The moment-curvature laws are derived from the structural parameters of the steel and the geometrical parameters of the members and of the connections, by following the recommendations of [18]. In Figure 9, $Q$ accounts for any lateral force causing the moment in the joint and $Q_{\mathrm{y}}$ is the yielding value of $Q ; \theta$ and $\Delta$ are deformation quantities (rotation angle and displacement, respectively). The lengths of the plastic hinges are determined according to [18]; in most of the cases, these lengths are close to half of the depth of the member. 


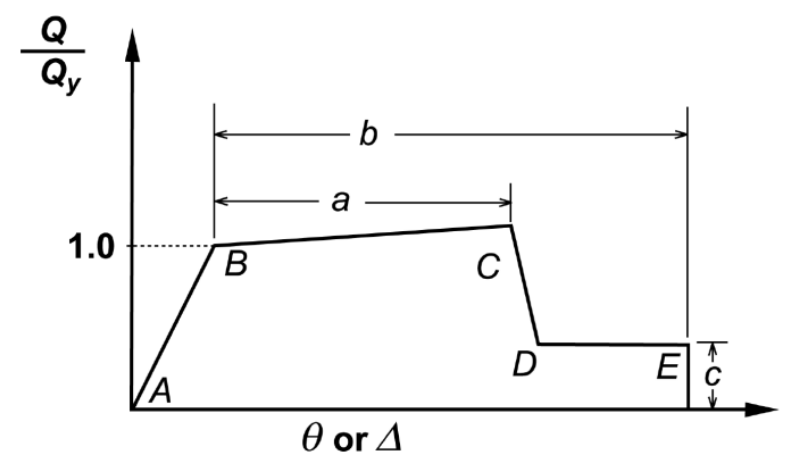

Figure 9. Moment-rotation law of a plastic hinge [18]

The model displayed in Figure 9 is also used to represent the axial failure of the braces of the CBF buildings. For tensioned braces, the values of parameters $a, b$ and $c$ are selected as indicated by [18] for "Braces in Tension". For compressed braces, parameters $a, b$ and $c$ are selected as $a=b=c=0$; this reflects a brittle buckling behavior.

\section{PUSH-OVER ANALYSES}

This section describes the results of the 2-D nonlinear static (push-over) analyses of the buildings described in section 3. As discussed previously, the variation of the lateral pushing forces along the height of the buildings is defined in two ways: uniform (corresponding to constant acceleration, e.g. approximately proportional to the mass of each floor) and modal (as the first modal shape) [7]. Only the contribution of the first mode is considered, since, in most of the analyzed situations, more than $75 \%$ of the total mass participates in the fundamental mode in the direction under consideration [18], see Table 3. To determine the target drifts, the demanding spectra are obtained from the former and current Colombian design codes $[1,5]$ and from the previous and the recently-issued microzonation for Bogotá [2, 4], Figure 2 and Figure 4, respectively [20]. For LS (Life Safety) such spectra are intended to correspond to 475 years return period, and for IO (Immediate Occupancy) and CP (Collapse Prevention) they correspond to 72 and 970 years, respectively [18]. The target drifts are determined, by intersecting the capacity curves and the demand spectra, as indicated in 
ATC-40 [8]. Given the rather high lateral flexibility of these buildings, the soil-structure interaction is not accounted for. Second-order analyses are performed; however, in most of the cases the differences with the first-order analyses are small.

Figure 10, Figure 11 and Figure 12 display the capacity curves of the buildings with, respectively, Moment-Resisting Frames, Concentric-Braced Frames and Eccentric-Braced Frames; the buildings have been designed for the most demanding "Piedemonte-B" Zone (newer microzonation, Figure 3). In Figure 10, Figure 11 and Figure 12 the vertical axis depicts the base shear coefficient, i.e. the base shear force normalized with the weight of the building, and the horizontal axis represents the drift angle, i.e. the relative displacement of the top floor in terms of percentage of the height of the building. In a given building, the capacity curves which correspond to the $x$ and $y$ directions (Figure 6 and Figure 7) and to uniform and modal pattern variations are plotted together. Point "•" indicates the onset of the first plastic hinge, which is coincident with the end of the linear branch. Points " $O$ ", " $\triangle$ " and " $\diamond$ "correspond to Target Drifts IO, LS and CP, respectively; omitted points mean that the capacity curve does not intersect the demanding spectrum, i.e. there is collapse. The reference [20] contains similar curves for the buildings designed for the other seismic zones (Figure 1 and Figure 3). 


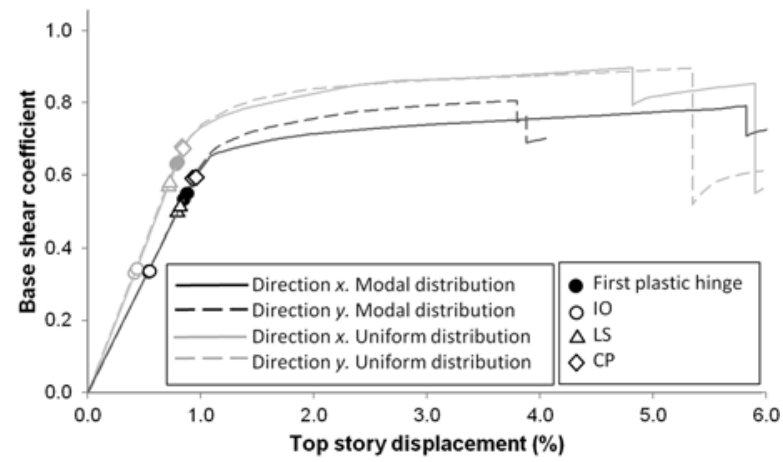

(a) Building 5-6 $\times 6-\mathrm{MRF}$

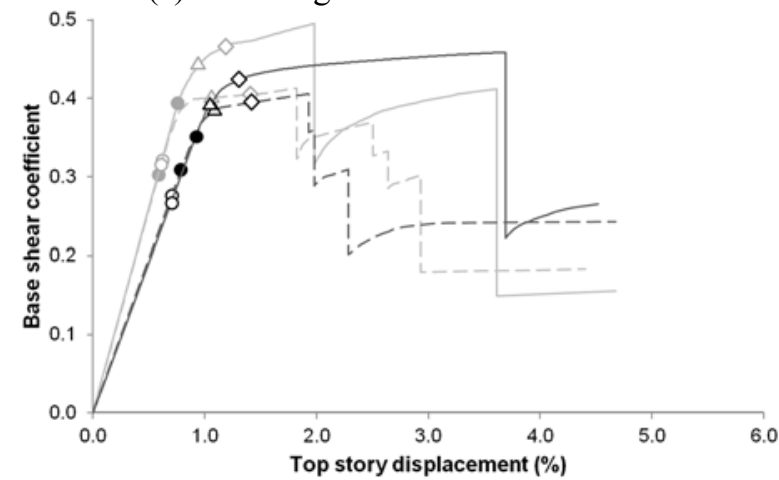

(c) Building 10-6 $\times 6-\mathrm{MRF}$

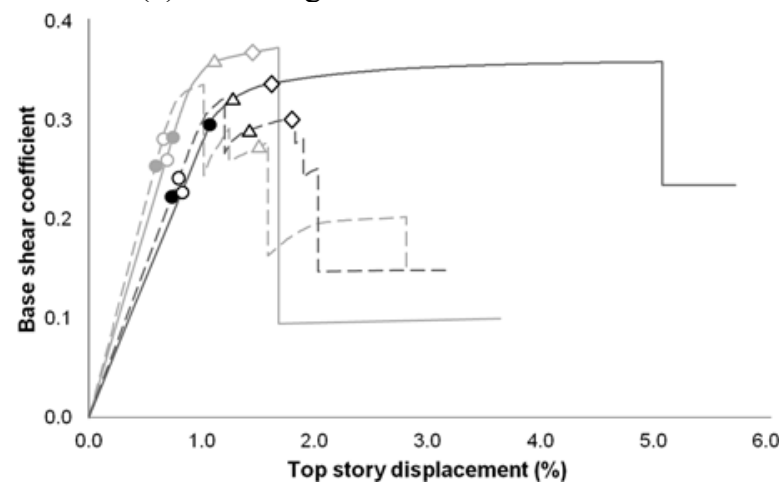

(e) Building 15-6 6 6-MRF

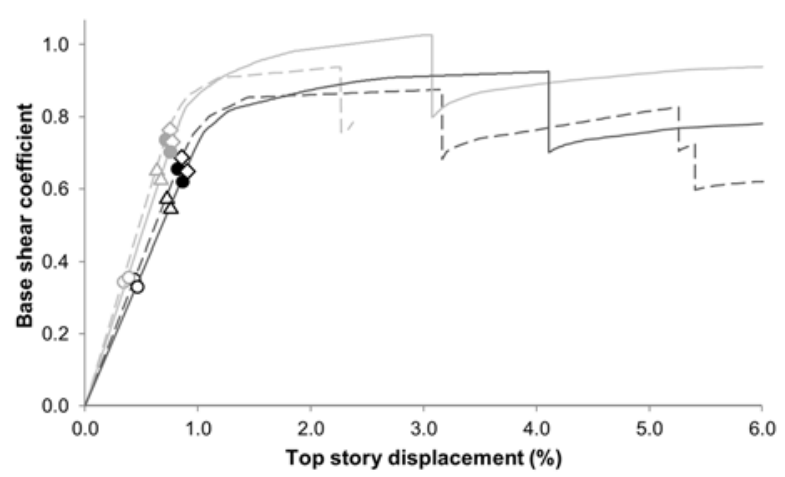

(b) Building 5-8 $\times 8-\mathrm{MRF}$

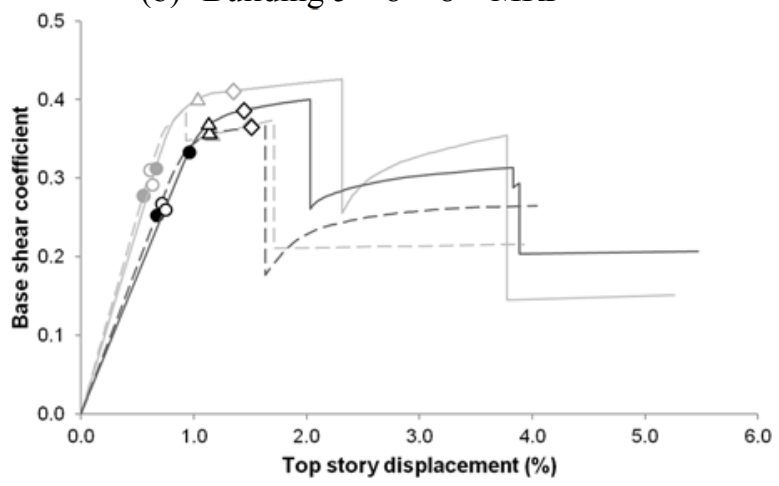

(d) Building 10-8 $\times 8-\mathrm{MRF}$

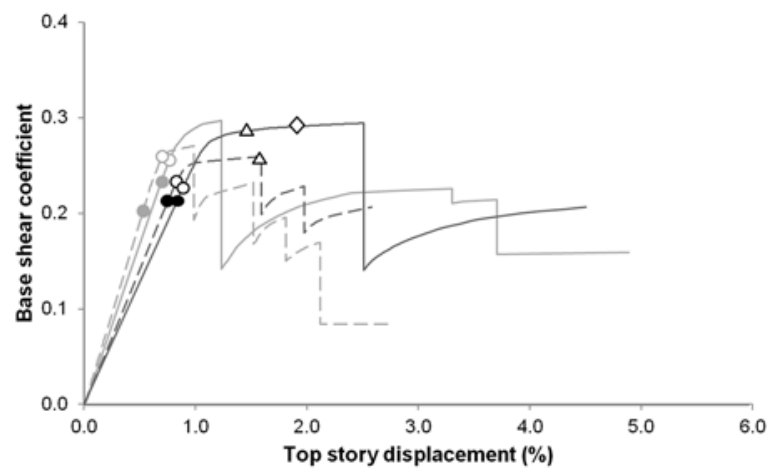

(f) Building 15-8 $\times 8-\mathrm{MRF}$

Figure 10. Capacity curves and Target Drifts of buildings with Moment-Resisting Frames. Zone "Piedemonte-B" (newer microzonation, Figure 3) 


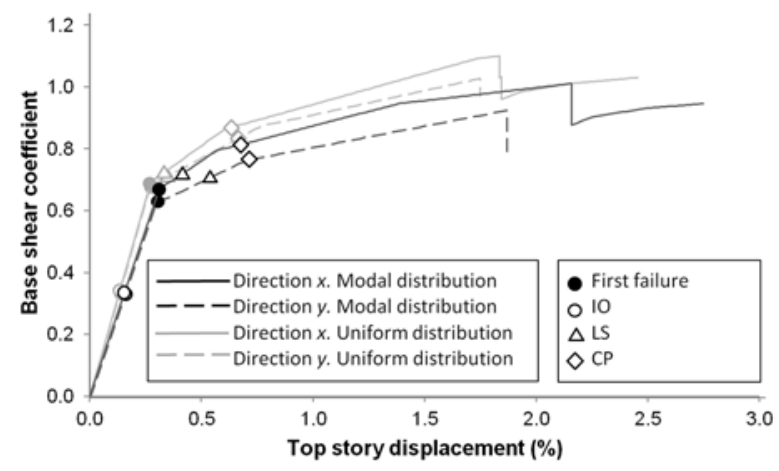

(a) Building $5-6 \times 6-\mathrm{CBF}$

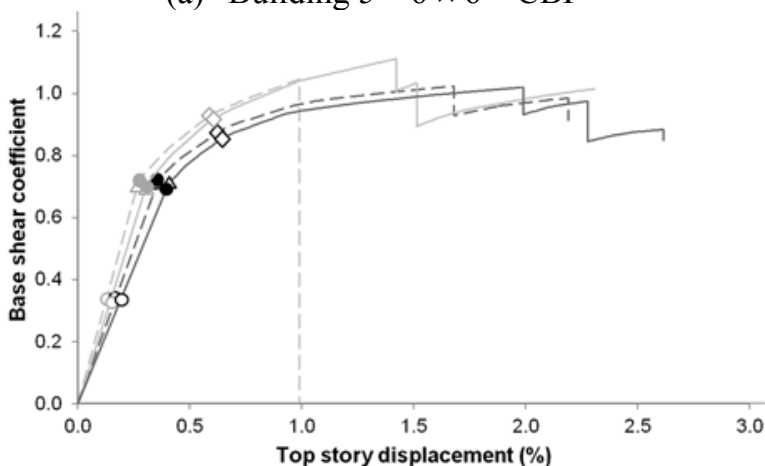

(c) Building $10-6 \times 6-\mathrm{CBF}$

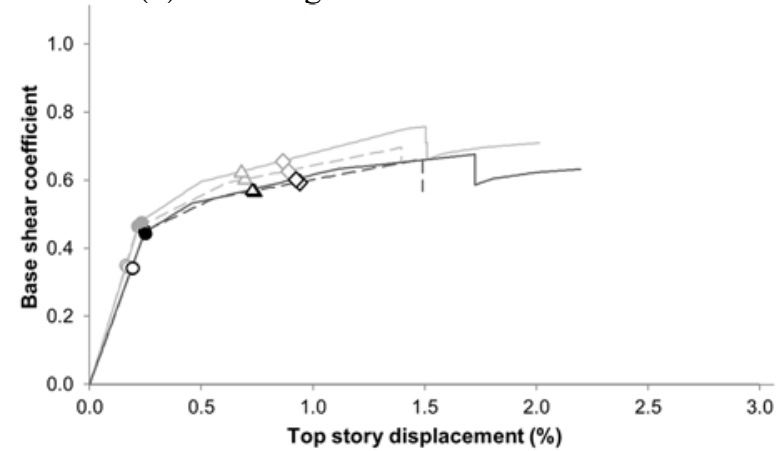

(e) Building $15-6 \times 6-\mathrm{CBF}$

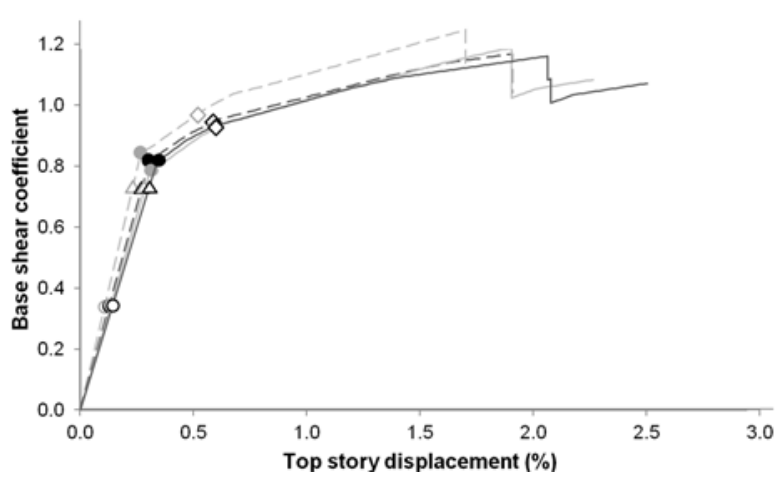

(b) Building $5-8 \times 8-\mathrm{CBF}$

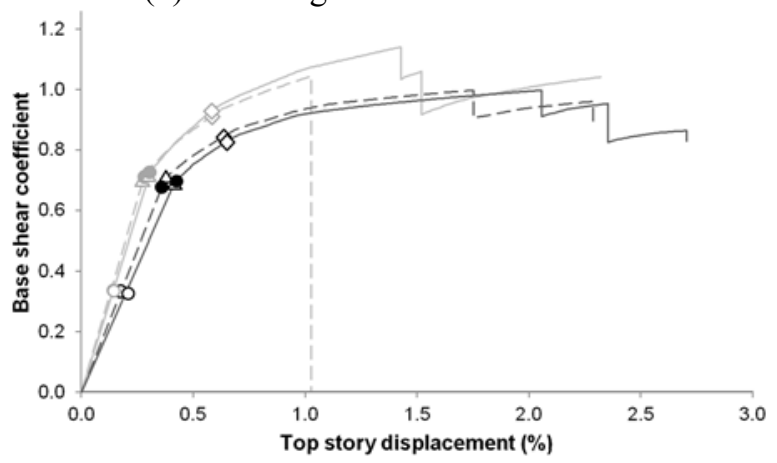

(d) Building $10-8 \times 8-\mathrm{CBF}$

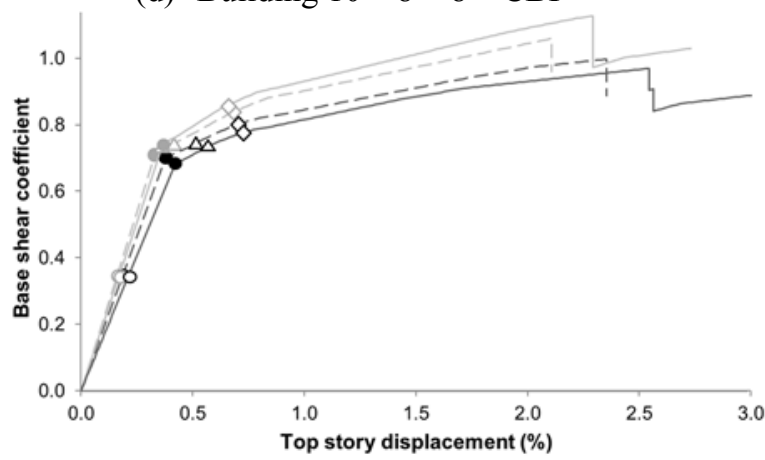

(f) Building $15-8 \times 8-\mathrm{CBF}$

Figure 11. Capacity curves and Target Drifts of buildings with Concentric-Braced Frames. Zone "Piedemonte-B" (newer microzonation, Figure 3) 


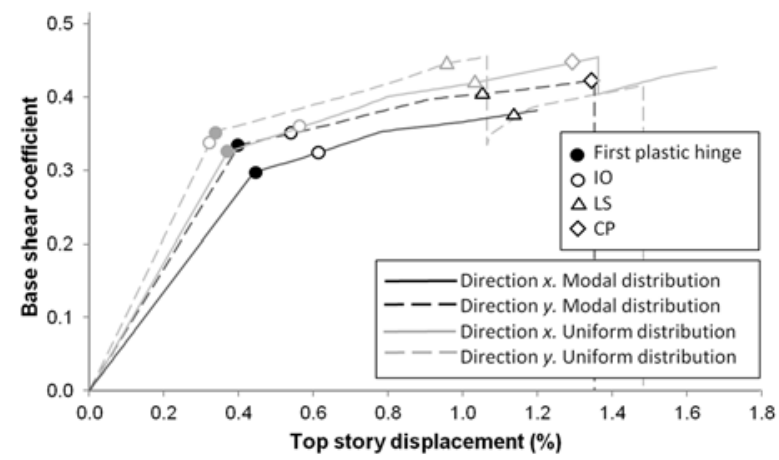

(a) Building 5-6 $\times 6-\mathrm{EBF}$

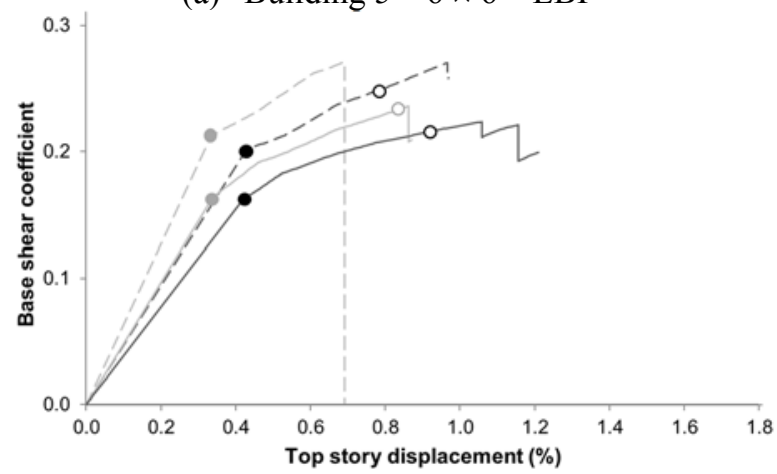

(c) Building 10-6 $\times 6-\mathrm{EBF}$

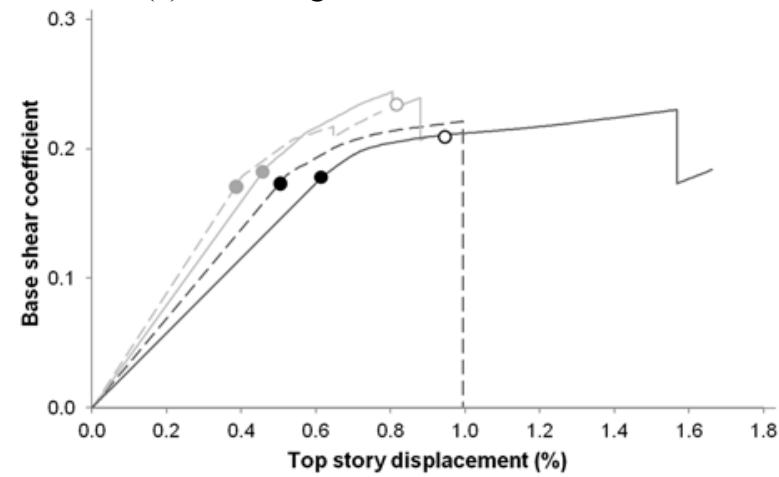

(e) Building $15-6 \times 6-\mathrm{EBF}$

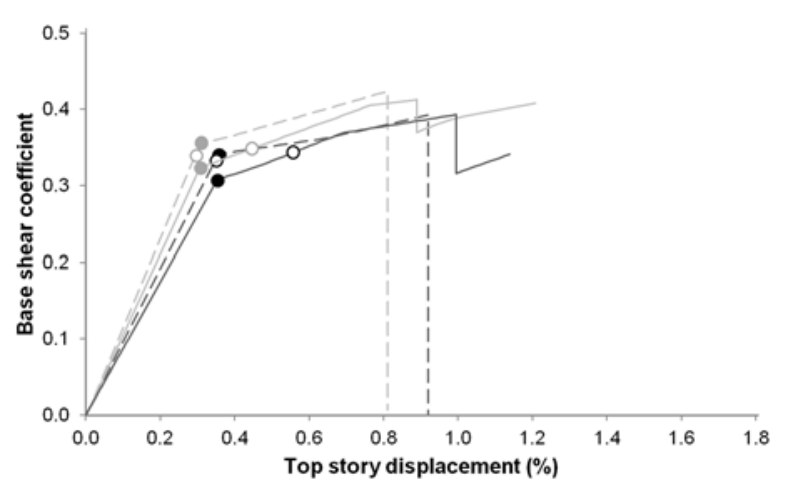

(b) Building 5-8 $\times 8-\mathrm{EBF}$

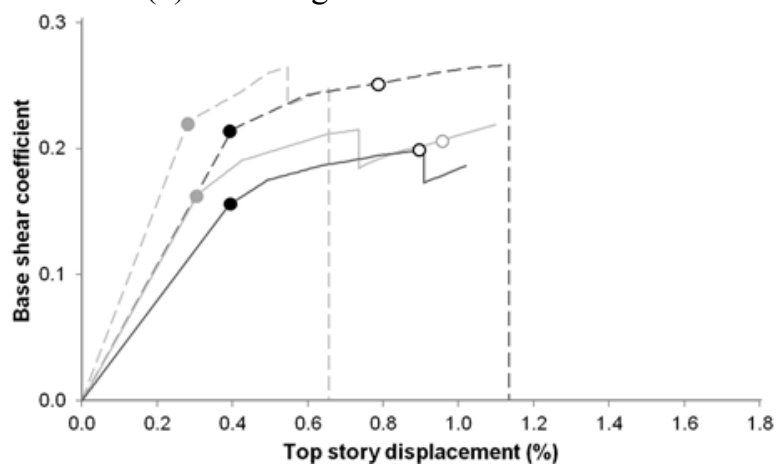

(d) Building 10-8 $\times 8-\mathrm{EBF}$

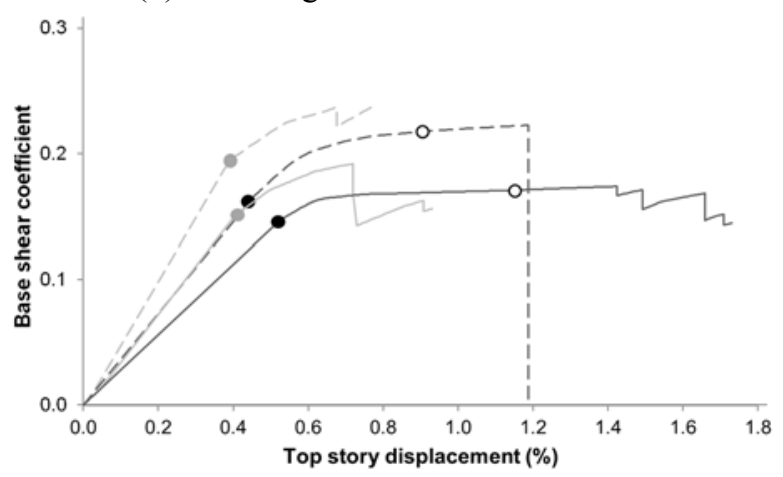

(f) Building 15-8 $\times 8-\mathrm{EBF}$

Figure 12. Capacity curves and Target Drifts of buildings with Eccentric-Braced Frames. Zone "PiedemonteB" (newer microzonation, Figure 3)

\section{DISCUSSION}

The observation of Figure 10, Figure 11 and Figure 12 provides the following conclusions on the influence of the involved parameters:

- Direction. The capacity curves for the $x$ and $y$ directions are rather similar both in the linear and nonlinear ranges; this resemblance refers to the vertical ordinates, the onset of yielding (points $\bullet$ ) and the Target Drifts IO, LS and CP. This conclusion shows similar 
levels of efficiency in the seismic designs in both directions.

- Vertical distribution. Since the vertical ordinate is proportional to the base shear, the modal distribution can be deemed more demanding than the uniform one; this fact can be observed in all the cases.

- Span-length. Comparison among the left and right pairs of curves $(6 \times 6$ and $8 \times 8$, respectively) shows that the capacity curves and the performance points of the buildings with span-lengths 6 and $8 \mathrm{~m}$ are rather analogous.

- Earthquake-resisting system. For all the analyzed buildings, the yielding and collapse displacements for MRF are higher than those of EBF; in their turn, such displacements are greater than those of CBF. Those differences can be explained by the inherent largest flexibility of MRF buildings compared to EBF and CBF ones; among EBF and CBF, the increase of ductility generated by the eccentricity of the braces implies larger yielding and collapse displacements. In terms of forces, the yielding and collapse forces for CBF are higher than those of MRF; in their turn, such forces are greater than those of EBF. Those differences can be explained by the inherent largest strength of CBF buildings compared to MRF ones; among MRF and EBF, the last have less force strength because of the high relevance of the shear-flexural behavior of the link.

- Number of floors. The yielding and collapse displacements for the 5, 10 and 15-story buildings with equivalent earthquake-resisting systems are similar. The capacity curves show that the seismic strength in terms of base shear coefficient is only slightly influenced by the number of levels; the taller the buildings, the lowest the base shear coefficient.

For each capacity curve, the damage intervals suggested by the research project RISK-UE [23] are adopted. "ND" (No Damage) corresponds to drift displacements lower than $0.7 \Delta_{y}$, "SD" (Slight Damage) corresponds to drift displacements between $0.7 \Delta_{\mathrm{y}}$ and $\Delta_{\mathrm{y}}$, "MD" 
(Moderate Damage) corresponds to drift displacements between $\Delta_{\mathrm{y}}$ and $\Delta_{\mathrm{y}}+0.25\left(\Delta_{\mathrm{u}}-\Delta_{\mathrm{y}}\right)$, "ED” (Extensive Damage) corresponds to drift displacements between $\Delta_{\mathrm{y}}+0.25\left(\Delta_{\mathrm{u}}-\Delta_{\mathrm{y}}\right)$ and $\Delta_{\mathrm{u}}$, and "HD" (Heavy Damage, that meaning collapse) corresponds to drift displacements higher than $\Delta_{\mathrm{u}} . \Delta_{\mathrm{y}}$ and $\Delta_{\mathrm{u}}$ are, respectively, the yielding and ultimate (collapse) displacements. For a proper seismic behavior, Target Drifts for IO, LS and CP should correspond, respectively, either to $\mathrm{SD}, \mathrm{MD}$ and $\mathrm{ED}$ or to smaller damage intervals [24]. According to this criterion, Table 5 displays the adequacy of the levels of damage corresponding to each of the three considered Target Drifts. "YES" / "NO" indicate satisfactory / unsatisfactory performance and "-" means that the corresponding performance point does not exist because the capacity curve and the demand spectrum have no intersection; certainly, this can be understood as highly unsatisfactory performance.

Table 5. Seismic performance of the prototype buildings. "Piedemonte B" zone (newer microzonation)

\begin{tabular}{|c|c|c|c|c|c|c|}
\hline \multirow{2}{*}{ Building } & \multicolumn{2}{|c|}{ Target Drift IO(*) } & \multicolumn{2}{|c|}{ Target Drift LS $(*)$} & \multicolumn{2}{|c|}{ Target Drift $\mathrm{CP}(*)$} \\
\hline & Direction $x$ & Direction $y$ & Direction $x$ & Direction $y$ & Direction $x$ & Direction $y$ \\
\hline $5-6 \times 6-\mathrm{MRF}$ & YES / YES & YES / YES & YES / YES & YES / YES & YES / YES & YES / YES \\
\hline $5-8 \times 8-\mathrm{MRF}$ & YES / YES & YES / YES & YES / YES & YES / YES & YES / YES & YES /YES \\
\hline $5-6 \times 6-\mathrm{CBF}$ & YES / YES & YES / YES & YES / YES & YES / YES & YES / YES & YES / YES \\
\hline$-\mathrm{CBF}$ & YES / YES & YES / YES & YES / YES & YES/YES & YES / YES & YES / YES \\
\hline $5-6 \times 6-\mathrm{EBF}$ & YES / NO & YES / YES & NO / NO & NO / NO & YES / YES & YES / YES \\
\hline $5-8$ & NO / NO & YES / YES & $-1-$ & $-1-$ & $-1-$ & $-1-$ \\
\hline RF & YES / YES & YES / NO & YES / YES & YES / NO & YES / YES & YES / YES \\
\hline $8-\mathrm{MRF}$ & YES / YES & NO / NO & YES / YES & NO / NO & YES / YES & YES / YES \\
\hline $6-\mathrm{CBF}$ & YES / YES & YES / YES & YES / YES & YES / YES & YES / YES & YES / YES \\
\hline$-\mathrm{CBF}$ & YES / YES & YES / YES & YES / YES & YES / YES & YES / YES & YES / YES \\
\hline $6-\mathrm{EBF}$ & NO / NO & NO / - & $-1-$ & $-1-$ & $-1-$ & $-1-$ \\
\hline$-\mathrm{EBF}$ & NO / NO & NO / NO & $-1-$ & $-1-$ & $-1-$ & $-1-$ \\
\hline MRF & YES / YES & NO / YES & YES / YES & NO / NO & YES / YES & YES / YES \\
\hline$-\mathrm{MRF}$ & NO / NO & NO / NO & NO / - & NO / - & YES / - & YES / - \\
\hline$-\mathrm{CBF}$ & YES / YES & YES / YES & NO / NO & NO / NO & YES / NO & YES / YES \\
\hline $15-8 \times 8-\mathrm{CBF}$ & YES / YES & YES / YES & YES / YES & YES / YES & YES / YES & YES / YES \\
\hline $15-6 \times 6-\mathrm{EBF}$ & NO / NO & NO / NO & $-1-$ & $-1-$ & $-1-$ & $-1-$ \\
\hline $15-8$ & NO / NO & NO / NO & $-1-$ & $-1-$ & $-/-$ & $-1-$ \\
\hline
\end{tabular}

(*) First / second values correspond to modal and uniform distributions, respectively

Table 5 provides the following conclusions on the influence of the involved parameters:

- Direction. The performances for the $x$ and $y$ directions are rather similar. 
- Vertical distribution. The performances for the uniform and modal distributions are rather similar.

- Span-length. The performances for $6 \times 6$ and $8 \times 8$ buildings are rather similar.

- Earthquake-resisting system. Globally speaking, CBF buildings exhibit a more adequate behavior than the MRF ones while the performance of EBF buildings is unacceptable in most of the cases. The highly adequate performance of the CBF buildings can be explained by the over-conservative design of columns and beams [17].

- Number of floors. By and large, the tallest considered buildings demonstrate a seismic performance worse than the shorter ones.

Figure 13, Figure 14 and Figure 15 describe the damage progression for buildings $15-8 \times 8$ $-\mathrm{MRF}, 5-8 \times 8-\mathrm{CBF}$ and $5-8 \times 8-\mathrm{EBF}$, respectively. Such buildings are designed for the "Piedemonte B" zone (Table 1); the depicted combinations of hinges and of failures correspond to modal distribution of the pushing forces and to $y$ direction (black dashed capacity curves in Figure 10.f, Figure 11.b and Figure 12.b). In Figure 13 and Figure 15, the meanings of symbols $\circ, \circ, \circ$ and $\bullet$ have been established as indicated in [18]: $\circ$ corresponds to the onset of yielding (corner point B in Figure 9) and $\odot, \circ$ and $\bullet$ correspond to acceptance criteria IO, LS and CP, respectively [18]. In Figure 14 a similar criterion is also considered for the tensioned braces while the compressed braces, because of their fragile behavior, have only the code $\bullet$; noticeably, in the tensioned braces point $\bullet$ corresponds to the final segment of the yielding branch (near corner point $C$ in Figure 9). The last sketches in Figure 13, Figure 14 and Figure 15 correspond to the rightest (collapse) point in the black dashed curves in Figure 10.f, Figure 11.b and Figure 12.b, respectively; the other sketches are basically uniformly distributed along the nonlinear segment of such curves. Results from Figure 13, Figure 14 and Figure 15 provide the following conclusions: 
- Figure 13 shows that the collapse mechanism is extremely brittle since virtually all the damage is concentrated in the first floor columns, with little damage in the beams; this observation can be basically extended to the other MRFs [20] yet the shorter building are more ductile. Given that the MRF buildings were designed fulfilling the code requirements aiming to guarantee ductility, this conclusion highlights the difficulty of predicting the actual collapse mechanism from merely linear analyses.

- Figure 14 shows that the CBF buildings perform satisfactorily since all of the damage is concentrated in the braces and, prior to collapse, involves a relevant number of them. Noticeably, after the buckling of the compressed braces and the yielding of the tensioned braces, the remaining structural members (e.g. columns and beams) are still capable to resist the pushing lateral forces [17]. These observations can be broadly extended to the other CBFs [20].

- Figure 15 shows that the EBF buildings perform satisfactorily since all of the damage is concentrated in the dissipative segments of the beams (link and adjoining parts). However, the collapse mechanism is extremely brittle since virtually all the damage is concentrated in the first floor. These observations can be broadly extended to the other EBFs [20]. 

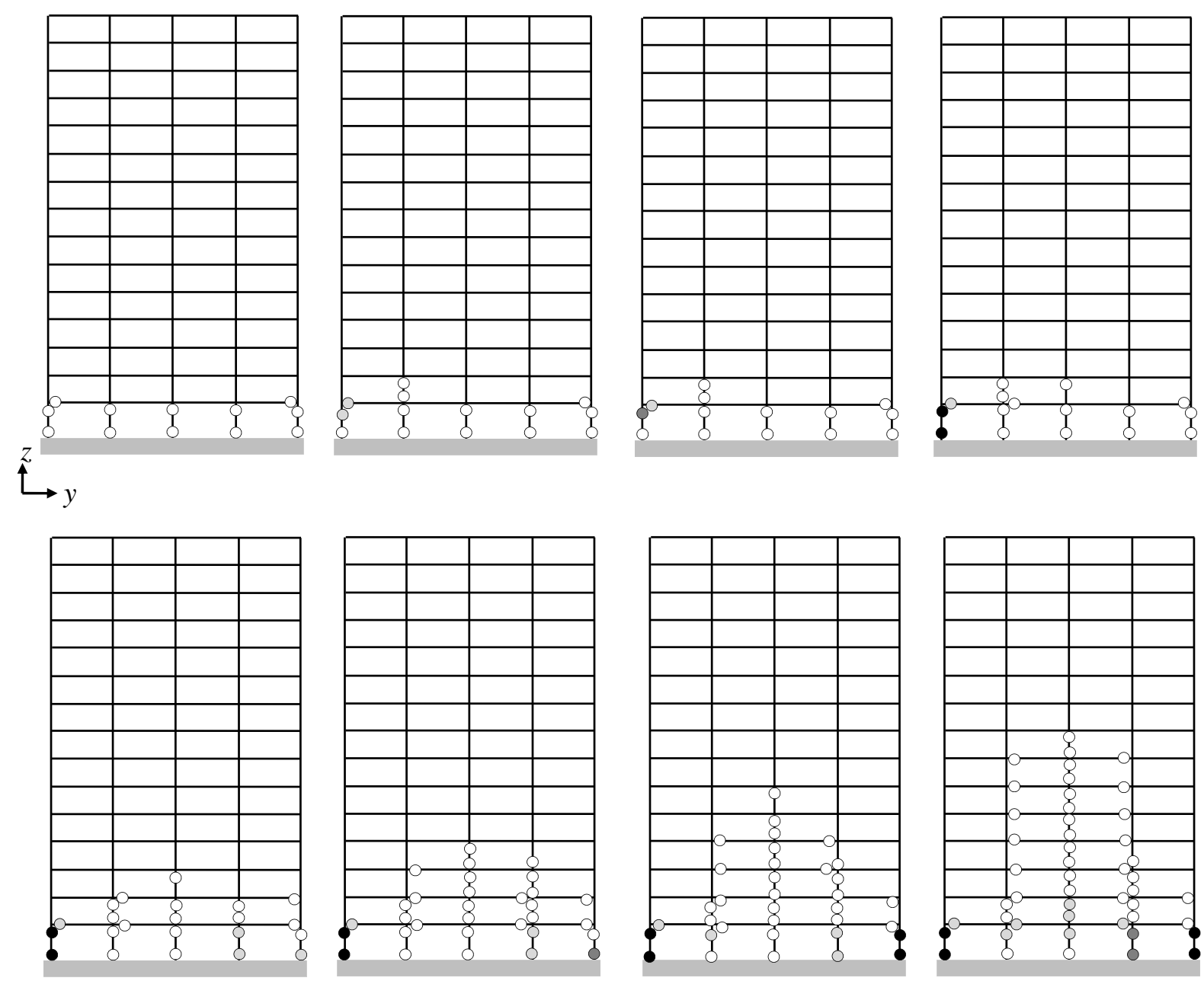

Figure 13. Hinge progression sequence for the $15-8 \times 8-$ MRF building, modal distribution and $y$ direction. Zone "Piedemonte-B" (newer microzonation, Figure 3). ०: yielding, ०: IO, ०: LS, • : CP [18]
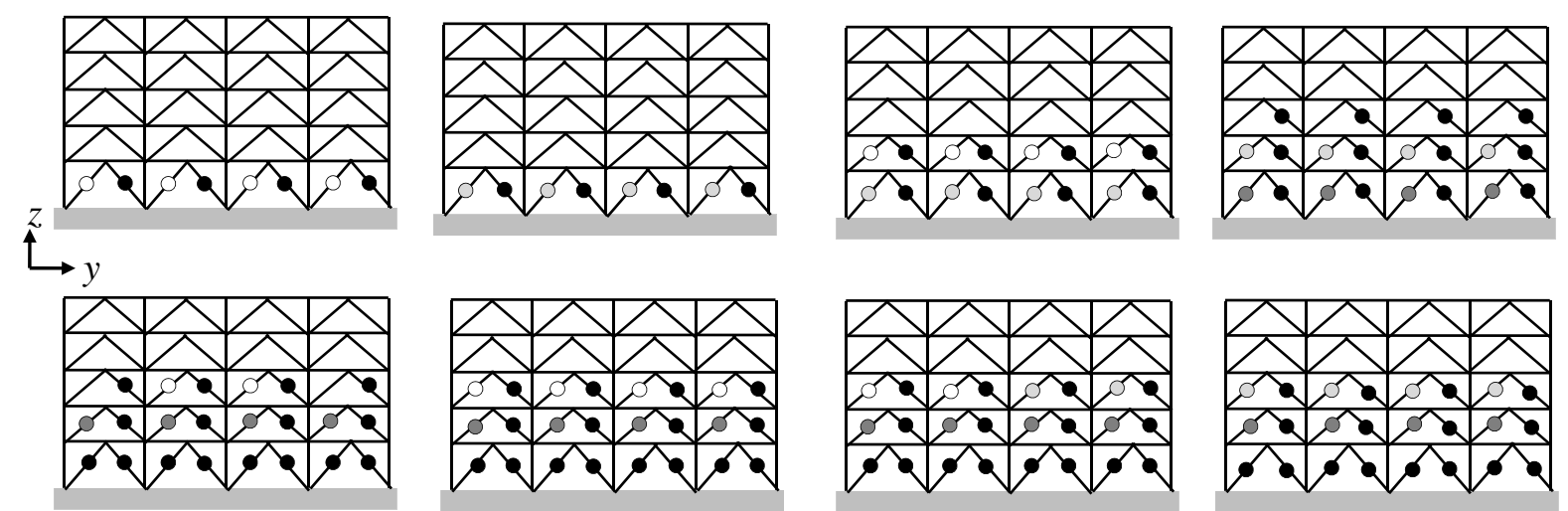

Figure 14. Failure progression sequence for the $5-8 \times 8-\mathrm{CBF}$ building, modal distribution and $y$ direction. Zone "Piedemonte-B" (newer microzonation, Figure 3). $\odot:$ yielding, $\circ:$ IO,,$:$ LS, $\bullet:$ CP [18] 

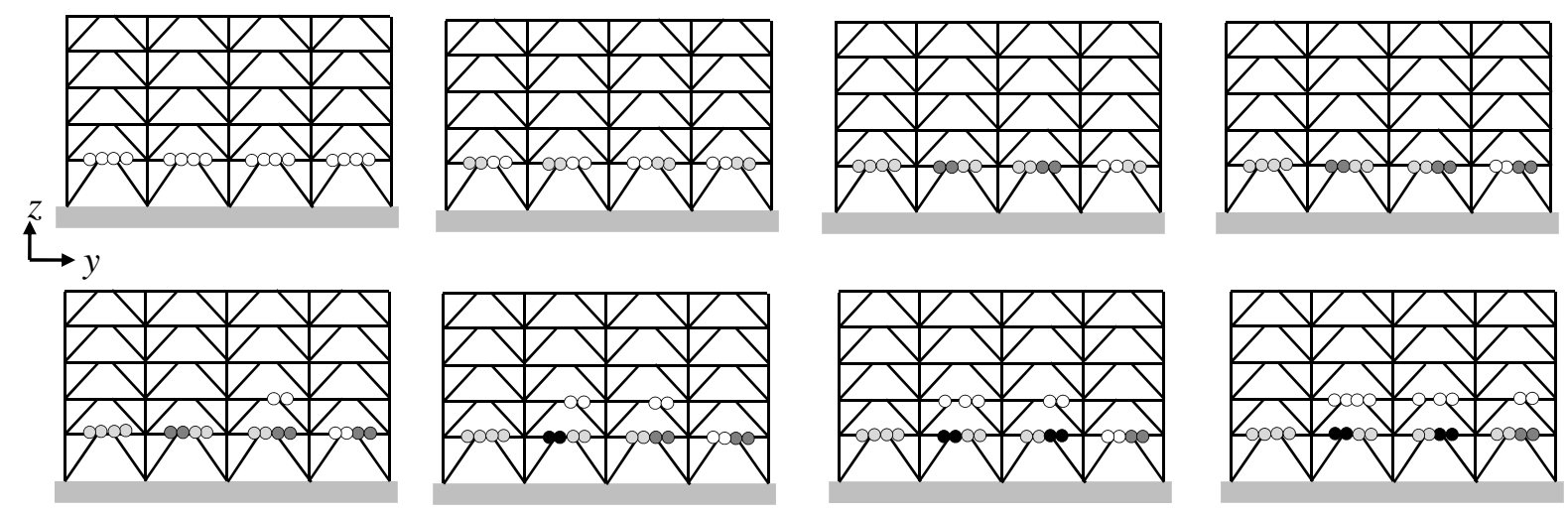

Figure 15. Hinge progression sequence for the $5-8 \times 8-$ EBF building, modal distribution and $y$ direction. Zone "Piedemonte-B" (newer microzonation, Figure 3). ० : yielding, ०: IO, ०: LS, • : CP [18]

Following the classic equal-displacement approach [6], the response reduction factor $R$ is determined from the capacity curves [25-27] depicted in Figure 10, Figure 11 and Figure 12. Since Table 2 shows that the fundamental periods of the buildings are clearly out of the short period range [28], the correction for short periods is not deemed necessary. The influence of the hysteretic characteristics is indirectly taken into account in the design of the push-over approach; moreover, some studies [29] have pointed out the little influence of the hysteretic characteristics of the structure compared to other effects. $R$ factor is determined as the ratio between the collapse and the yielding displacements; $R=\Omega R_{\mathrm{d}}$ where $\Omega$ is the over-strength factor (the ratio between the actual and the design strength) and $R_{\mathrm{d}}$ is the ductility factor (the ratio between the elastic and the actual strength). The obtained values of $R, \Omega$ and $R_{\mathrm{d}}$ are displayed in Table 6.

Figures in Table 6 show that the response reduction factors tend to decrease with the number of floors (Figure 13) and the values for the EBF are smaller than those for MRF and CBF; as well, $R$ factors for CBF and MRF are similar (Figure 14 and Figure 15). On the other side, the values of $R$ are little sensitive to the direction, to the vertical variation of the pushing forces and to the span-length. 
Table 6. Response reduction factor $R$ in the $x / y$ directions. "Piedemonte B" zone (newer microzonation)

\begin{tabular}{ccccccc}
\hline \multirow{2}{*}{ Building } & \multicolumn{2}{c}{ Over-strength factor $(\Omega)(*)$} & \multicolumn{2}{c}{ Ductility factor $R_{\mathrm{d}}(*)$} & \multicolumn{2}{c}{$R$ factor $\left(R=\Omega R_{\mathrm{d}}\right)(*)$} \\
& Direction $x$ & Direction $y$ & Direction $x$ & Direction $y$ & Direction $x$ & Direction $y$ \\
\hline $5-6 \times 6-\mathrm{MRF}$ & $1.45 / 1.41$ & $1.47 / 1.39$ & $4.77 / 4.34$ & $2.81 / 4.87$ & $6.91 / 6.11$ & $4.14 / 6.77$ \\
$5-8 \times 8-\mathrm{MRF}$ & $1.33 / 1.45$ & $1.30 / 1.27$ & $3.53 / 2.68$ & $3.11 / 2.41$ & $4.70 / 3.88$ & $4.05 / 3.05$ \\
$5-6 \times 6-\mathrm{CBF}$ & $1.49 / 1.59$ & $1.52 / 1.49$ & $4.69 / 4.38$ & $3.99 / 4.02$ & $7.00 / 6.95$ & $6.05 / 6.00$ \\
$5-8 \times 8-\mathrm{CBF}$ & $1.45 / 1.49$ & $1.37 / 1.47$ & $4.14 / 4.38$ & $4.59 / 3.69$ & $6.00 / 6.53$ & $6.29 / 5.42$ \\
$5-6 \times 6-\mathrm{EBF}$ & $1.27 / 1.41$ & $1.26 / 1.32$ & $2.44 / 2.61$ & $2.69 / 2.34$ & $3.09 / 3.68$ & $3.40 / 3.08$ \\
$5-8 \times 8-\mathrm{EBF}$ & $1.25 / 1.28$ & $1.14 / 1.78$ & $2.30 / 2.21$ & $2.06 / 2.21$ & $2.88 / 2.83$ & $2.37 / 2.54$ \\
\hline $10-6 \times 6-\mathrm{MRF}$ & $1.30 / 1.23$ & $1.28 / 1.05$ & $3.06 / 2.07$ & $1.84 / 2.85$ & $3.98 / 2.55$ & $2.36 / 3.00$ \\
$10-8 \times 8-\mathrm{MRF}$ & $1.22 / 1.35$ & $1.47 / 1.37$ & $1.75 / 1.92$ & $1.84 / 2.20$ & $2.14 / 2.59$ & $2.71 / 3.02$ \\
$10-6 \times 6-\mathrm{CBF}$ & $1.54 / 1.64$ & $1.45 / 1.43$ & $3.32 / 3.07$ & $3.15 / 2.37$ & $5.11 / 5.04$ & $4.57 / 3.38$ \\
$10-8 \times 8-\mathrm{CBF}$ & $1.45 / 1.59$ & $1.43 / 1.41$ & $3.24 / 2.97$ & $3.54 / 2.18$ & $4.70 / 4.71$ & $5.05 / 3.07$ \\
$10-6 \times 6-\mathrm{EBF}$ & $1.39 / 1.43$ & $1.35 / 1.30$ & $1.80 / 1.78$ & $1.70 / 1.60$ & $2.50 / 2.54$ & $2.31 / 2.08$ \\
$10-8 \times 8-\mathrm{EBF}$ & $1.28 / 1.32$ & $1.27 / 1.12$ & $1.82 / 1.94$ & $2.29 / 2.02$ & $2.33 / 2.55$ & $2.90 / 2.27$ \\
\hline $15-6 \times 6-\mathrm{MRF}$ & $1.22 / 1.33$ & $1.33 / 1.06$ & $3.96 / 3.76$ & $2.27 / 2.48$ & $4.83 / 2.16$ & $3.03 / 2.64$ \\
$15-8 \times 8-\mathrm{MRF}$ & $1.39 / 1.30$ & $1.25 / 1.33$ & $2.16 / 1.44$ & $2.06 / 1.37$ & $3.00 / 1.87$ & $2.57 / 1.83$ \\
$15-6 \times 6-\mathrm{CBF}$ & $1.54 / 1.59$ & $1.49 / 1.43$ & $4.34 / 3.95$ & $3.56 / 4.07$ & $6.67 / 6.27$ & $5.31 / 5.81$ \\
$15-8 \times 8-\mathrm{CBF}$ & $1.39 / 1.52$ & $1.43 / 1.49$ & $4.56 / 4.03$ & $4.55 / 4.55$ & $6.33 / 6.11$ & $6.50 / 6.79$ \\
$15-6 \times 6-\mathrm{EBF}$ & $1.30 / 1.30$ & $1.28 / 1.39$ & $1.96 / 2.11$ & $1.56 / 1.56$ & $2.55 / 2.75$ & $2.00 / 2.17$ \\
$15-8 \times 8-\mathrm{EBF}$ & $1.19 / 1.27$ & $1.39 / 1.25$ & $2.26 / 1.36$ & $1.96 / 1.58$ & $2.70 / 1.72$ & $2.73 / 1.97$ \\
\hline
\end{tabular}

(*) First / second values correspond to modal and uniform distributions, respectively

Comparison among the values in Table 6 and the assumed response reduction factors listed in Table 2 shows that, in virtually all the cases, the analyzed buildings do not possess the required ductility.

The work [30] contains a numerical study for steel MRF designed according to the European regulations for high seismicity regions; overall comparison among the obtained values of the response reduction factor from that work and from Table 6 shows that both are relatively similar. As well, the aforementioned decrease of $R$ with the increased number of floors is also confirmed.

The Eurocode 8 [7] states that for MRF and EBF buildings with Ductility Class High (DCH) the behavior factor $q$ (which is equivalent to the $R$ factor) can be obtained as $q=5 \alpha_{\mathrm{u}} / \alpha_{1}$, where factor 5 plays the role of the ductility factor $R_{\mathrm{d}}$ and $\alpha_{\mathrm{u}} / \alpha_{1}$ corresponds to the overstrength factor $\Omega$. If none push-over analysis has been carried out, for MRF and EBF 
buildings like those considered in this work, $\alpha_{\mathrm{u}} / \alpha_{1}=1.3$ and 1.2 , respectively. If capacity curves are available, the arising value of $\alpha_{u} / \alpha_{1}$ can be considered, with a top limit equal to 1.6. For CBF with V-bracing (chevron braces) the Eurocode 8 states that $q=2.5$. Comparison with Table 6 provides the following conclusions:

- MRF. $R_{\mathrm{d}}$ factor is smaller than 5 in all the cases, the difference being higher for taller buildings. $\alpha_{u} / \alpha_{1}(\Omega)$ is smaller than 1.3 in a relevant number of cases; the top limit (1.6) is never reached.

- CBF. The value of $q(R)$ indicated by the Eurocode 8 is clearly exceeded in all the cases. As discussed previously, this satisfactory behavior can be explained by the late cooperation of columns and beams [17].

- EBF. $R_{\mathrm{d}}$ factor is clearly smaller than 5 in all the cases, the difference being even higher for taller buildings. $\alpha_{\mathrm{u}} / \alpha_{1}(\Omega)$ is bigger than 1.2 in virtually all the cases; the top limit (1.6) is, by far, never reached.

\section{CONCLUSIONS}

This work presents a numerical vulnerability assessment of eighteen 5, 10 and 15-story steel buildings. These buildings are selected to represent the vast majority of similar buildings recently erected in Bogotá, Colombia. The span-lengths are $6 \mathrm{~m}$ and $8 \mathrm{~m}$, and three lateral resistant systems are considered: moment resisting frames (MRF) and concentrically and eccentrically braced frames (CBF and EBF, respectively); only chevron braces are used. The vulnerability is estimated by static push-over analyses by assuming two patterns for the vertical variation of the pushing forces: uniform and modal.

Main conclusions of this study: 
- Seismic performance. CBF buildings exhibit an adequate behavior, the performance of EBF is unacceptable in most of the cases and the behavior of MRF buildings is intermediate. The highly adequate performance of the CBF buildings can be explained by the over-conservative design of columns and beams. By and large, the tallest considered buildings demonstrate a worse seismic performance. The performance of the considered prototype buildings is insensitive to the input direction, the vertical variation of the pushing forces and the span-length.

- Collapse mechanism. The collapse mechanism for MRF buildings is extremely brittle. Since those buildings fulfill the ductility requirements, this shows the difficulty of predicting the collapse mechanism from merely linear analyses. In the CBF buildings all of the damage is concentrated in a relevant number of the braces; after the failure of the braces, columns and beams still hold capacity. In the EBF buildings the collapse mechanism is extremely brittle since the damage is concentrated in the link segments of the first floor beams.

- Response reduction factor. The values of the $R$ are little sensitive to the direction, to the vertical variation of the pushing forces and to the span-length. Two major trends are observed: $R$ factor decreases with the number of floors and the values for the EBF are smaller than those for MRF and CBF. In virtually all the cases, the analyzed buildings do not possess the ductility which is required by the Colombian design code.

- Eurocode 8. Comparison with the prescriptions of the shows that they are overconservative for MRF and EBF buildings but are under-conservative for CBF buildings.

\section{ACKNOWLEDGEMENTS}

This work has received financial support from the Spanish Government under projects CGL2008-00869/BTE and CGL2011-23621. 


\section{REFERENCES}

[1] NSR-98. (1998). Normas Colombianas de Diseño y Construcción Sismo Resistente. Asociación Colombiana de Ingeniería Sísmica, (in Spanish).

[2] Decreto 523. Microzonificación sísmica de Bogotá. (2010). Alcaldía mayor de Bogotá, (in Spanish).

[3] Montaña M.A., López Almansa F. Seismic vulnerability analysis of steel buildings in Bogotá, Colombia. (2012). 15th World Conference on Earthquake Engineering (15WCEE). Lisbon, Portugal. Art. 529 (publication in CD).

[4] Decreto 196. Microzonificación sísmica de Bogotá. (2006). Alcaldía mayor de Bogotá, (in Spanish).

[5] NSR-10. (2010). Normas Colombianas de Diseño y Construcción Sismo Resistente. Asociación Colombiana de Ingeniería Sísmica, (in Spanish).

[6] Priestley M.J.N., Calvi G.M., Kowalsky M.J. (2007). Displacement-Based Seismic Design of Structures, IUSS Press.

[7] EN-1998. Eurocode 8: Design of structures for earthquake resistance. (2004). European Committee for Standarization.

[8] ATC-40. (1996). Seismic Evaluation and Retrofit of Concrete Buildings. Applied Technology Council.

[9] AISC (2010). Steel Construction Manual. American Institute on Steel Construction.

[10]ASTM A572 / A572 M-12. (2012). Standard Specification for High-Strength Low-Alloy ColumbiumVanadium Structural Steel. DOI: 10.1520/A0572_A0572M-12.

[11]ASTM A36 / A36 M-08. (2008). Standard Specification for Carbon Structural Steel. DOI: 10.1520/A0036_A0036M-08.

[12] Becker R., Ishler M. (1996). Seismic Design Practice for Eccentrically Braced Frames. Steel Tips. Structural Steel Educational Council.

[13] Hashemi S.H. (2011). Ductility and Ultimate Strength of Eccentric Braced Frame. 2011 International Conference on Advanced Materials Engineering IPCSIT, Singapore.

[14]FEMA-350. (2000). Recommended Seismic Design Criteria for New Steel Moment-Frame Buildings. Federal Emergency Management Agency.

[15] AISC-327 (2010). Seismic Design Manual. American Institute on Steel Construction.

[16] Seek M.W., Murray T.M. (2009). Seismic strength of moment end-plate connections with attached concrete slab. AISC Report No. 3279.

[17] Becker R. (1995). Seismic Design of Special Concentrically Braced Steel Frames. Steel Tips. Structural Steel Educational Council.

[18]FEMA 356. (2000). Prestandard and commentary for the seismic rehabilitation of buildings. Federal Emergency Management Agency.

[19] ASCE 41-06. (2006). Seismic Rehabilitation of Existing Buildings. American Society of Civil Engineers.

[20] Montaña M.A. Seismic vulnerability analysis of mid-height steel buildings in Bogotá. (2013). Doctoral Dissertation. Technical University of Catalonia.

[21] Tapia-Hernández E., Tena-Colunga A. (2008). Behavior of regular steel moment resisting concentrically braced frames (MRCBFs) in seismic zones. 14 ${ }^{\text {th }}$ World Conference on Earthquake Engineering. Beijing, China.

[22] Mahmoudi M., Zaree M. (2011). Evaluating the overstrength of concentrically braced steel frame systems considering members post-buckling strength. International Journal of Civil Engineering. Vol. 9(1) 59-62.

[23] Milutinovic Z.V., Trendafiloski G.S. (2003).Vulnerability of current buildings, Work-Package 4 of RISK_UE Project, European Commission, EVK4-CT-2000-00014.

[24] Pujades L.G., Barbat A.H., González-Drigo R., Ávila J., Lagomarsino S. (2012). Seismic performance of a block of buildings representative of the typical construction in the Eixample district in Barcelona (Spain). Bulletin of Earthquake Engineering 10:1.331-349.

[25] Miranda E. Strength Reduction Factors in Performance-Based Design. (1997). EERC Berkeley.

[26] Cuesta I., Aschheim M.A., Fajfar P. (2003). Simplified R-Factor Relationships for Strong Ground Motions. Earthquake Spectra, 19(1) 25-45.

[27] Kang C.K., Choi B.J. (2011). New approach to evaluate the response modification factors for steel moment resisting frames. International Journal of Steel Structures. 11:3 275-286.

[28] Nassar A.A., Krawinkler H. (1991). Seismic Demands for SDOF and MDOF Systems. Stanford University, (The John A. Blume Earthquake Engineering Center) Report No. 95.

[29]Zhang J., Zhao, J.X. (2008). Strength Reduction Factor (R Factor) Model and Inelastic Response Spectra for Forward-Directivity Ground Motion, 14WCEE, Beijing, China, Paper ID: 05-01-0068.

[30] Ferraioli M., Lavino A., Mandara A. (2012). Behaviour Factor for seismic design of moment-resisting steel frames. $15^{\text {th }}$ World Conference on Earthquake Engineering. Lisbon, Portugal. 